\title{
ZYGMUNT BAUMAN: ENTENDIMIENTO DE UN UNIVERSO INFINITO
}

\section{ZYGMUNT BAUMAN: THE UNDERSTANDING OF AN INFINITE UNIVERSE}

\section{Alberto González Pascual}

Universidad Rey Juan Carlos y del Centro Universitario Villanueva

adscrito a la Universidad Complutense de Madrid

alberto.pascual@urjc.es

Palabras clave: Zygmunt Bauman, racionalidad líquida, amor líquido, adiaforización, alienación.

Krywords: Zygmunt Bauman, liquid rationality, liquid love, adiaphorization, alienation.

Resumen: Como homenaje a las aportaciones intelectuales, morales y políticas de las obras de Zygmunt Bauman, en este artículo (dedicado a su memoria) se realiza una síntesis dialéctica de varios de los conceptos más fundamentales que desarrolló a lo largo de su prolífica carrera (la adioforización, la racionalidad líquida, el amor líquido, la marginación de los pobres, la minusvaloración de los que son diferentes subsumidos en categorías de subhumanos y la urgencia de la toma de conciencia para actuar éticamente). En la exposición crítica se dejan emerger capas de análisis procedentes de otros pensadores (como Kant, Freud, Platón, Lacan, Levinas y Marx) con el fin de proporcionar un mayor esplendor, flexibilidad y amplitud al pensamiento trascendente y potencialmente utópico de Bauman.

Abstract: As a tribute to the intellectual, moral and political contributions of the works of Zygmunt Bauman, this article (in memoriam) presents a dialectical synthesis of the core concepts that he developed throughout his prolific career (adiaphorization, liquid rationality, liquid love, the marginalization of the poor, the undervaluation of those who are different subsumed into subhuman categories and the urgency of the awareness to act ethically). In the critical exposition, layers of analysis from other thinkers (such as Kant, Freud, Plato, Lacan, Levinas and Marx) are allowed to emerge in order to provide Bauman's transcendent and potentially utopian thinking with greater splendor, amplitude and flexibility. 
¿Quién es el tercero que camina siempre a tu lado?

(Amado Zygmunt)

Si cuento, solo estamos tú y yo juntos

pero cuando levanto la vista al camino blanco

siempre hay otro caminando a tu lado

escabulléndose envuelto en un mantón marrón,

lleva capucha (y pijama,

no sé si es hombre, mujer o chispa del ancestro,

un rey celestial, fantasía del Otro)

-pero ¿quién es ese a tu otro lado?

Eres esfera cuyo centro está en todas partes,

y la circunferencia en ninguna.

Degeneración solo aquí, sobre la Tierra,

y no en todas las partes del Universo.

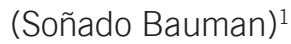

\section{l. Introducción: revelación y entusiasmo}

En estos tiempos de incipiente oscuridad no es popular ni particularmente cómodo el intento de demostrar, en la teoría y en la práctica, el ideal puro de fenómenos como la fraternidad y el amor a la inteligencia. Pese a lo cual, la decisión en torno a cómo hacer un homenaje útil (en el sentido crítico que demandaba Sócrates de quienes se atrevían a escucharlo) que refleje lo descubierto y aprendido en las obras de Zygmunt Bauman², casi no me

1. Poema aportado por el autor de este artículo en homenaje al espíritu perseverante de Zygmunt Bauman (en él se parafrasean unos versos de $L a$ Tierra Baldía de T.S. Eliot, al tiempo que toma inspiración de un comentario de Alexandre Koyré a propósito del pensamiento de Nicolás de Cusa).

2. Zygmunt Bauman nació el 19 de noviembre de 1925 y falleció el 9 de enero de 2017, a los 91 años. Natural de la ciudad de Poznan, situada en el centro occidental de Polonia. Entre sus experiencias biográficas consta que fue víctima de los nazis. Desde 1948 comenzó a dar clases de sociología en la Universidad de Varsovia, donde se convirtió en catedrático en 1964. Cuatro años más tarde, él y su familia fueron exiliados como consecuencia de una campaña antisemita impulsada por el régimen comunista. Así se convirtió en un refugiado por segunda vez y sus experiencias de pobreza y marginación lo llevaron hacia una sociología comprometida y explícitamente moral. Después de varios puestos docentes temporales en las universidades de Tel Aviv, Haifa y Melbourne, al fin, en 1971, se estableció en Gran Bretaña. Allí dirigió el departamento de sociología de la Universidad de Leeds durante veinte años, hasta 1991, y continuó como emérito hasta su muerte. Su primer libro mundialmente conocido fue Modernidad y Holocausto (1989), una clara advertencia del potencial genocida latente en cualquier sociedad moderna que busca privilegiar el orden y la eficiencia sobre la moral, la responsabilidad ética y el cuidado del prójimo. A principios de este siglo publicó su influyente obra Modernidad líquida (2000), en la que desplegó su metáfora más celebrada, adoptada por activistas e intelectuales de todo el mundo para denunciar y resistir discursivamente los efectos de la globalización y la creciente deshumanización y mercantilización de las relaciones sociales. Entre los muchos honores que le concedieron destacó el premio Theodor W. Adorno en 1998. 
ocupó tiempo tras la aceptación de realizar este comentario para la Revista Internacional de Pensamiento Político. Con el recuerdo, evocado desde el fondo de la mente, de un relámpago que quiebra el silencio de un falso refugio, entendí que el modo de realizarlo, el motivo correcto, debía ser la interpretación del desorden moral y político acumulado a los pies de las leyes y creencias de una sociedad rebajada, sitiada y líquida (como la diagnosticó Bauman), las cuales, como columnas que crujen cuando el suelo es agitado, sostienen una humanidad exasperada bajo la forma de un proyecto complicado y falible de civilización infinita. Presento un esfuerzo por describirlo, aun con diversos límites y abreviaciones, utilizando solamente algunos de los cuantiosos, lúcidos y originales conceptos analíticos y prácticos creados por este sabio nacido en Poznan.

Trayendo al centro el lacónico inciso de Kant sobre la falta de Juicio en proclamados eruditos ${ }^{3}$, sostengo que no es el caso que nos atañe, pues quien haya leído la prolífica producción de ensayos de Zygmunt tiene la intuición de que él sí sabe elegir los casos concretos que disecciona

3. En relación al ingenio natural que está más allá de toda educación (lo que popularmente es etiquetado como "talento" por la cultura posindustrial), Kant dirime que "la falta de esta capacidad es, de hecho, lo que llamamos necedad y tal defecto no tiene remedio (...aunque cualquiera) puede muy bien llegar, a base de estudio, hasta la misma erudición", lo que nunca será suficiente dado que si la razón se usa inadecuadamente (es decir, aquel que no sabe aplicar en la práctica el conocimiento que tiene) porque hay carencia de ingenio, pues, no se producirá el entendimiento e igualmente faltará el Juicio y solo se accedería al conjunto que pertenece a la doxa. Ver Kant, Immanuel. Crítica de la razón pura. Taurus, Madrid, 2017, p. 180 para que caigan bajo las reglas universales. Tal vez su agudeza para no equivocarse denota que asumió durante toda su vida como investigador de la condición humana el desafío kantiano de superar los escasos conocimientos intelectuales que hemos sido capaces de forjar para alcanzar lo universal, y, en concreto, para poder preparar nuestro entendimiento para la ética (como el otro proyecto inacabado de prepararnos para unas condiciones tales que los derechos inalienables de la humanidad pueden ser entendidos con las concordancias que son necesarias en relación con los derechos de los pobres, los marginados e incluso de los que son asesinos de otros seres humanos ${ }^{4}$ ). El combate de Bauman, racional y material, ha sido contra la ensoñación, la fantasía y la superstición con la que la sociedad se dirige entusiasmada (bajo el zumbido narcótico de la Schwärmerei5) hacia lugares sin llegada ni retorno, precipitándose la pérdida de la realidad. La idea del Bien le precede.

4. Aquí citaré como contrapunto las conocidas palabras de Marx relativas a que "el crimen no puede suprimirse más que cuando se haya colocado al hombre en condiciones tales que se haya vuelto imposible" que puedan cometerse.

5. El término Schwärmerei, de larga tradición en la teología, filosofía, psiquiatría y literatura alemanas desde la Reforma hasta el Romanticismo, designa de un modo general aquello que se cala como un delirio fanático (contenido en la metáfora luterana del enjambre de abejas que zumba sin pausa, cegado sobre el lugar en el que se halla la verdad). Igualmente, sirvió durante mucho tiempo como palabra común para englobar en una misma categoría los casos de visiones, sueños, profecías y alucinaciones de pacientes e "iluminados" descarriados. Véase para un estudio pormenorizado el artículo de Rodríguez Baigorria, Martin, "La Ilustración alemana y los dilemas de la Schwärmerei” en Aufklärung. Revista de filosofía, 2014, 1 (julio-diciembre). 


\section{Los síntomas de la deshumanización de los extraños y diferentes}

Hay una marca condensada en las estrategias discursivas del sujeto occidental para abordar el misterio, la incertidumbre, el extrañamiento y las diferencias de ideas y formas que a este le resultan arriesgadas e incluso peligrosas en el Otro, quien antes fue aprendido dentro de la sociedad de acogida como el exponente de lo opuesto a la familia, la religión y la escuela, los cuales qué otras cosas son sino herederos gentiles de los reyes taumatúrgicos que lo (nos) han concebido y adorado (al sujeto) cual niño hasta el presente (actuando como los prístinos aparatos del Estado moderno que siembran las creencias y los conocimientos empíricos, mistificados ambos por un propósito necesariamente ideológico en el inconsciente de cada proyecto de mente antes de su preciso nacimiento, dotando así a cada recién nacido de un discurso y un número ${ }^{6}$ pendiente de trámite para ser admitido en la sociedad). Esta marca, sig-

6. El significante "número" lo desplazo, primero, a su vertiente neoplatónica como símbolo del logos (lo real; la academia de Platón), es decir, lo que ya existe y que a través de la activación coordinada (dialéctica) de la inteligencia y la imaginación queda al descubierto para la conciencia (de tal forma que todo fenómeno que puede ser reducido a un número existe matemáticamente para el entendimiento). Segundo, a su vertiente psicológica (logoterapia; la escuela de Víctor E. Frankl), por tanto, de lo que da sentido a la existencia para orientar la conducta práctica del sujeto hacia una realización plena (ética y neuróticamente útil). Y tercero, a su vertiente mercantil, como signo de un valor que posee una cotización dentro del mercado capitalista y que puede variar según la evolución interna de este (lo que genera un número=plusvalía para una parte del mercado no ubicuo dentro del sistema lacaniano, expresión de la negación a la asimilación o integración tanto de lo primitivo como de lo que es valorado como lo nuevo (detonante de la inestabilidad general) queda formalizada por Zygmunt Bauman como un significante antropoémico ${ }^{7}$ (a su decir exacto una "estrategia"): un rasgo del lenguaje transferido a la realidad psíquica y cultural mediante el cual activamos un esfuerzo cognitivo y a la vez moralizante para expulsar de los límites de nuestra civilización aquello que se siente por ella como una amenaza a su orden y al uno que hemos asimilado, aunque haya sido aceptado por trauma, como la unidad necesaria. Este "vómito" (fobia émica), que ejercita el lanzamiento de lo diferente hacia lo que nos queda lejano o en "enclaves vigilados", se ha convertido en una fuerza motriz que gobierna el devenir de las posibilidades culturales y políticas que gestamos como sociedad y que ilustran los síntomas del enfermo, nuestra madre Europa, que tras su aparente resurrección ética al inicio de la segunda mitad del pasado siglo, ya solamente deambula terminal, pues aquel revivir careció de dialéctica, sin ojo ni supralogos ${ }^{8}$.

Con el coraje del héroe que solo lo es por méritos propios, el de aquel que puede ser humillado sin que nadie sienta miedo por las represalias, Bauman se preocupa

-la curva de la alienación de la sociedad-; la escuela de Jeremy Bentham y Adam Smith).

7. Bauman, Zygmunt. La ética posmoderna. Siglo XXI, Madrid, 2009, p. 183.

8. En referencia a la virtud de las virtudes (o también conocida como la estimativa, que evalúa la perfección de los valores que a su vez proporcionan la ponderación de la vida buena a las virtudes que, en su inicio, siendo naturales, aparecen imperfectas). Véase Plotino. Enéadas. Losada, Buenos Aires, 2005, p. 84 y ss. 
por entender tales síntomas para ir desgranando una teoría social ágil, que coloca a modo de cataplasma bajo nuestros sentidos obstruidos y que podrá si no curar, sí al menos aliviar la ansiedad -quizás anestesiarla- que nos sobreviene por la falta de entendimiento de los fenómenos sociales y su relación con la conducta humana; dicho de otro modo, nos aporta una especie de "sueño de Descartes"9 para empujarnos a la superación del desgarro existencial derivado de no parar de andar, sin salirnos del camino, a pesar de hacerlo sin saber, más allá de la función biológica que ocupa, cuál es el propósito totalizador que se oculta tras el significado literal que designa el propio acto de caminar hacia delante:

9. Aquí aludo a la interpretación de los sueños de René Descartes apuntada por el historiador Maxime Leroy en su obra sobre el filósofo francés. En el análisis de Leroy, sobre el que más tarde solicitará la opinión de Freud para contrastar sus conclusiones, basado en una paráfrasis narrada por un abad del siglo XVII, Adrien Baillet (quien es considerado el primer biógrafo de Descartes), todos los objetos, personas y visiones que recordaba Descartes de varios sueños que él mismo calificó como signos de epifanía, contenían los significantes del deseo inconsciente que le condujo durante toda su vida: adoptar la sindéresis para compensar los errores y pecados de su juventud, y de ese modo albergar al Espíritu de la Verdad (la decisión permanente y ascética de comprometer su vida con la reflexión filosófica y científica). Freud, claro está, matizaba esta interpretación tan evidente en relación con la sexualidad reprimida de Descartes (subrayando el famoso "melón" que aparece como regalo en el recuerdo de uno de los sueños). La extensa obra de Bauman puede ser recibida como una herramienta práctica para discernir una senda para la sindéresis. Ver Freud, Sigmund. Obras completas. Volumen 21 (192731) Amorrortu, Buenos Aires, 1976, pp. 198-206. Ver Leroy, Maxime. Descartes, le philosophe au masque. Rieder, Paris, 1929.
Propongo que los sentimientos ambivalentes y confusos que suscita la presencia de extraños -esos otros subdefinidos, subdeterminados, ni vecinos ni forasteros, aunque (incongruentemente) en potencia ambas cosas- se describan como proteofobia. El termino se refiere a la aprehensión provocada por la presencia de fenómenos multiformes y alotrópicos que tercamente desafían el conocimiento, tan adicto a la claridad, eliden su deber y debilitan las tan familiares retículas clasificatorias. ${ }^{10}$

He ahí, en el sintagma que encarnan "los fenómenos multiformes", un síntoma de la aversión a la totalidad de la humanidad por la humanidad y la catarsis regresiva que absorbe la mentalidad occidental mediante el desigual desarrollo institucional de las variantes del cristianismo ${ }^{11}$ y más

\section{Op. cit., Bauman, p. 185.}

11. El cristianismo primitivo, representado por el movimiento que lideraron Jesús y sus seguidores dentro de la tradición judía, implicó, entre otros factores, una disrupción con respecto a la noción de autoridad contenida en la visión escatológica de la basileia (el advenimiento del reino sagrado de Dios). La reinterpretación de la Tora que presentó el rabino de Galilea posicionó la basileia al servicio de la totalidad de la humanidad (incluidos los impíos, los sucios, los pecadores y los pobres), eliminando la diferenciación entre la santidad y la limpieza de los elegidos y de los rectos en relación con la anonimización de la multitud (símbolo de los restos excrementales). En la visión y praxis resultante, el mensaje defendía que todo el mundo, sin restricción alguna (por razón de paganismo, etnia, género, estatus social o estigmatización moral o cultural), estaba invitado a unirse y disfrutar del reino (el pueblo de Israel perdía su exclusividad) puesto que la basileia se hallaba en el interior de cada persona por su propia naturaleza humana (la cuestión era aceptar la unidad trascendente dentro de la diversidad o continuar reprimiéndola). Sin embargo, el desarrollo histórico posterior enseguida recaerá en subrayar enunciados y categorías del patriarcado que siempre fueron cruciales en la 
tarde por la causalidad estructural del capitalismo y su sincronía con el nacionalis$\mathrm{mo}^{12}$. Volviendo al síntoma, en el sistema

tradición hebrea, y que terminaron por reproducirse en la evolución del cristianismo en combinación con la tradición política y los principios económicos inherentes a las estructuras ideológicas de los siglos II al V. La unidad trascendente de la totalidad (universalidad) de la humanidad como creación de Dios podemos relacionarla con la idea de universalidad o totalidad ideada quince siglos más tarde por Kant como la pluralidad considerada como unidad. En efecto, Kant identificada una conciencia "pura, originaria e inmutable" (la "apercepción trascendental") mediante la cual sería posible el entendimiento objetivo de lo diverso, o dicho de otra forma, la mente solo puede pensar la identidad del yo en medio de la diversidad por medio del concepto a priori (la causa) y no empírico (responde a reglas a priori). Por tanto, el entendimiento solo es imaginable por la necesidad de la unidad de conciencia, lo que es extrapolable a la dimensión sobre el espacio y el tiempo que abrió el discurso de Jesús (al traer la esperanza del futuro a la experiencia del presente). En ese contexto teológico, la sacralidad de la humanidad solo podía entenderse como unidad universal, es decir, en aplicación al entendimiento de la totalidad de la humanidad como concepto. Los objetivos que fija Bauman, judío de nacimiento, para encarrilar su deducción (en el sentido Kantiano -quid jurisde alegar razones, pruebas y derechos) reflejan la tensión justificativa de la unidad de la humanidad como constante política y religiosa. Véase op. cit., Kant, p. 116 y pp. 136-137. Ver Schüssler Fiorenza, Elisabeth. In memory of her. A feminist theological reconstruction of Christian origins. Crossroad, New York, 1983 ,pp. 119-121

12. Aquí me limitaré a recomendar la perspectiva de Althusser en "Ideología y aparatos ideológicos del Estado" por un lado. Y la de Rosa Luxemburgo en "La acumulación del capital" por otro. En relación a esta segunda, resumo una de sus ideas seminales que regeneró la tradición marxista comúnmente aceptada en su tiempo (aunque la mayoría de la élite intelectual representativa de ese movimiento en Alemania la despreció vehementemente): “(...) El proceso de de Freud este queda consignado como el indicio de un proceso represivo, de modo que aflora en la conducta del sujeto con la forma de prohibiciones o penitencias unas veces, y otras mediante satisfacciones sustitutivas que se repiten compulsivamente $^{13}$. Si lo reprimido es convenido como aquellas representaciones "inaceptables para la conciencia"14, el síntoma puede manifestarse como una estrechez ante el peligro (de lo prohibido), es decir, como el signo de la angustia sustanciado en aquello que amenaza al sujeto con retornar a una situación primigenia e infantil, como si repentinamente fuera de nuevo un niño desvalido y por siempre inacaba$\mathrm{do}^{15}$ (a modo de un segundo nacimiento

crecimiento no era meramente la consecuencia de leyes naturales que dirigían la producción capitalista sino (que la causa se hallaba) en la continua existencia de sectores precapitalistas en el país que el "capitalismo" capturó y llevó a su esfera de influencia. Una vez que este proceso se expandió a todo el territorio nacional, los capitalistas se vieron obligados a buscar otras partes de la tierra, otras tierras precapitalistas, para llevarlos al proceso de acumulación de capital que se alimentaba de lo que estuviera fuera de sí mismo". Por consiguiente, el nacionalismo se arma como el virus que propicia la efectividad de la expansión. Me planteo, por analogía, si no será este proceso un síntoma de la repetición compulsiva del acto "traumático" de expropiación adyacente a la pulsión de muerte. Ver el comentario sobre Luxemburgo contenido en Arendt, Hannah. Hombres en tiempos de oscuridad. Gedisa, Barcelona, 1990, p. 49 y siguientes.

13. Freud, Sigmund. Inhibición, sintoma y angustia. Amorrortu, Buenos Aires, 2016, p. 77.

14. Ibidem., pp. 15-17. En este sentido, Jacques André advierte del proceso causal que se inicia rápidamente hacia el desprendimiento del afecto (de lo que es reprimido)

15. "La existencia intrauterina de hombre se presenta abreviada en relación a la de la mayoría de los animales; es dado a luz más inacabado que estos. Ello refuerza el influjo del mundo exterior 
pero más traumático). En consonancia, al igual que ocurre con el genio vienés, Bauman tiene un objetivo primordial que fluye de una raíz originaria y eterna: diseccionar el significado de la dominación y el control que la cultura, como expresión de la superestructura, despliega en nuestro yo social para hacer de nosotros lo que no somos, una identidad sustraída, otro ser que por lo general deviene asustado y que busca la fantasía de una protección absoluta para atreverse a ocupar el lugar que desea nuestro inconsciente reprimido, y así proceder al descendimiento de la apariencia de bienestar y autocontrol. Bauman, con su característica habilidad para el juico analítico, nos presenta los efectos sociales y psíquicos (emocionales) que provocan el orden y la administración del espacio social por parte de los aparatos ideológicos de los estados, quienes alcanzarían su plenitud (concebida esta como certeza apodíctica) al instaurar un "mapeado cognitivo" en la conciencia del ciudadano, lo que a su vez tiene efectos sobre la comprensión del espacio social en el que deviene la vida material que el sujeto reproduce en términos morales:

En el espacio social mapeado cognitivamente, el extraño es alguien del que sabemos poco y deseamos saber aún menos. En el espacio moral, el extraño es alguien que

real, promueve prematuramente la diferenciación del yo respecto del ello, eleva la significatividad de los peligros del mundo exterior e incrementa enormemente el valor del único objeto que puede proteger de estos peligros y sustituir la vida intrauterina perdida. Así, este factor biológico produce las primeras situaciones de peligro y crea la necesidad de ser amado, del que el hombre no se librara jamás"; luego el amor es, como metáfora, la sustitución de la necesidad de dejar de sentir el peligro, pues, lo que está en sí inacabado equivale a la indefensión (que representa la forma primitiva de la angustia). Véase ibidem., p. 124. nos importa poco y nos sentimos tentados a que nos importe aún menos (...) por lo que es probable que sigamos cometiendo actos irracionales e inmorales, así como actos que son irracionales aunque morales, y otros que son racionales e inmorales. ${ }^{16}$

En efecto, Bauman refleja cómo se produce el desfallecimiento del entendimiento práctico sobre aquellas situaciones (los fenómenos) sobre las que no estamos enseñados para comprender, puesto que "desafían el conocimiento" y "debilitan las retículas clasificatorias". Necesariamente, para exponer la geometría de este padecimiento y las "maneras de controlar el problema" por parte de los mecanismos de dominación social, procederé al ejercicio de revisar el canon de la razón pura y el principio de la no contradicción para recorrer en un sentido crítico la deducción realizada por Bauman. Es fácil recordar que, para Kant, de las tres preguntas que, gracias al uso de la razón, podemos formularnos para, en la indagación que suscitan, llegar a alcanzar el sentido que debe para la condición humana, la decisiva (o trascendental) era “iqué puedo esperar?"17. En esta proposición (que, como expresé en la introducción, representa el ánimo del espíritu de verdad con el que se siente comprometido este comentario por el hecho de ser una cuestión teórica y práctica en simultaneidad) se contiene que para el hombre y la civilización hay algo que esperar: la felicidad. Como consecuencia, la dignidad de la felicidad vendría a quedar establecida por una ley absoluta que directamente sintetiza que aquélla es "el empleo de la libertad de un ser racional". Pocas dudas le caben a Bauman de que esa ley, cuya claridad debería ser de una proporcionalidad igual

16. Op. cit., Bauman, p. 189.

17. Op. cit., Kant, p. 630. 
y que conduciría a un fin práctico ("haz aquello mediante lo cual te haces digno de ser feliz"), se encuentra en realidad alienada por las experiencias del sujeto en la sociedad; dicho de otro modo, como advertía Kant, se cumple que "el sistema de la moralidad va indisolublemente ligado al de la felicidad, pero solo en la idea de la razón pura"18 (especulativa).

Consecuentemente, la infelicidad pura (tomada como el entendimiento nulo) del ciudadano contemporáneo debe conectarse con su impotencia para ejercer su libertad práctica en términos racionales. Bauman señala que en el instante en que no "sabemos seguir adelante" porque la diversidad de los fenómenos supera la uniformidad de la educación recibida (ajustada estratégicamente para dominar), sin certezas sobre las reglas que deben aplicarse ante lo reprimido, surge la demanda por una programación del espacio social en la que los sentimientos morales serían suprimidos al servicio de un sistema alternativo de creencias, opiniones y juicios que resuelven la problemática en una dirección: generando unos sentimientos extraviados con respecto al fin práctico de la felicidad pero que son tomados como significantes socialmente aptos para controlar el síntoma; lo que ayudaría a contextualizar las inclinaciones de las minorías y desfavorecidos a la hora de sentir atracción hacia discursos fascistas, xenófobos, sexistas o antisemitas que de un modo u otro les debilitan en el plano de los fenómenos empíricos tanto como que les alejan de la dignidad universal.

Entre las estrategias para dominar (y protegernos del extraño, del diferente y del extranjero), Bauman distingue entre la

18. Ibidem., p. 633. fágica (que incluye al otro. Es decir, el visitante o externo a debe apegarse para tener posibilidades de ser aceptado. Dispuesto a dejar de ser para volver a ser de acuerdo a un marco de referencia), y la émica (el visitante o externo a queda clasificado como lo diferente a lo nuestro. La condena social y normativa se hace evidente si el sujeto se atreve a prolongar su estancia entre nosotros tal y como es. La resistencia a dejar de ser para así seguir siendo, coloca al sujeto en una situación de peligro para sí del que es considerado el único responsable). La dominación impone de manera binaria una elección totalitaria (de "una u otra" entre esas opciones, las únicas posibles). La felicidad que es entendida por quien es nativo del lugar, pues, aquel que cree que pertenece debidamente antes que el resto (la multitud informe y excremental) al Estado, se la asegura (como garantía de orden) mediante discursos que apelan a la conservación de la seguridad identitaria e "instituciones correctivas para los fracasados y los recalcitrantes; el ostracismo cultural y la denigración de las costumbres extranjeras, con el atractivo de la asimilación cultural; el proselitismo nacionalista, con la posibilidad de repatriación y limpieza étnica; la igualdad de ciudadanía legalmente proclamada, con el control de la inmigración y las reglas de deportación"19. La contradicción de fines obviada en este encadenamiento de opuestos ha sido "democráticamente" legalizada, saltándose el principio del entendimiento puro analizado por Kant ${ }^{20}$. En este sentido, ¿un

19. Op. cit., Bauman, p. 184.

20. Kant se esforzó por diferenciar, en aras de obtener un conocimiento analítico, aquello que puede ser simultaneo con respecto a lo que puede ser sucesivo, y del mismo modo separó lo que es un juico determinado por una propiedad temporal, de aquel que es estrictamente analítico (que 
ordenan pueden contener fines racistas y, aspira a tener una validez universal). Por ejemplo, mediante el enunciado negativo de que una persona joven no puede ser una persona vieja al mismo tiempo, aunque sí lo terminará siendo en tiempos diferentes o sucesivos (obviamente, queda descuidado el carácter ideológico y culturalista en el sentido de que una persona joven puede comportarse en la práctica social como alguien precozmente viejo $\mathrm{y}$, al revés, un viejo puede comportarse de un modo regresivamente infantil). La intención de su razonamiento se explica mejor con la siguiente descripción: "Si digo que una persona no es culta, debo añadir la condición de simultaneidad, ya que quien es inculto en un momento puede ser culto en otro momento. Si afirmo, en cambio, «Ninguna persona inculta es culta», tenemos una proposición analítica, ya que la propiedad de la incultura formaria parte del sujeto (...) sin necesidad de añadir la condición de simultaneidad". Ver op. cit., Kant, p. 193. Por consiguiente, la complejidad discursiva a la que se enfrenta un sujeto en el mundo contemporáneo cae en la aporía de la causalidad y de la no contradicción, ya que unas veces actúa como un racista -formalmente no declarado- (exento de censura moral) que es asistido por leyes que le habilitan un deber práctico para serlo (protegiendo bienes públicos escasos y preservando la seguridad del estado y de los seres queridos), mientras que en otras ocasiones, por medio del mismo régimen normativo, adopta un conocimiento universal sobre la totalidad de la humanidad (la ayuda pública o privada calificada como "humanitaria", y asistiendo el acceso a la nacionalidad para extranjeros). Aunque sea de este modo, el razonamiento puro nos conduciría a elucidar una proposición analítica que validara que «ninguna persona racista es no racista». Sin duda, el dilema sobre el contenido de las políticas de inmigración europeas y la reproducción de la espacialización social, moral y estética (a través del mapa asistido por los medios de comunicación para ilustrar la llegada de inmigrantes "ilegales" y el miedo o precio por tratarles como seres humanos cuando son presentados como "no humanos" (en el sentido de "no iguales a nosotros") o solamente como "casi humanos" (solo "parcialmente como nosotros") reflejan la distorsión reglada que capta Bauman con su ingenio.

a la vez, de no discriminación de acuerdo a la dignidad de la felicidad? Y de la misma forma, ¿puedo comportarme como un racista hoy en un determinado supuesto y mañana, sucesivamente, decir tomar mis decisiones como alguien que combate ese mismo racismo en otro escenario diferente mientras que, simultáneamente, ejerzo en ambos momentos mi libertad racionalmente? Lo que aquí está en juego no es la secuencia temporal de los acontecimientos ni siquiera la hipocresía de los hombres en términos de moralidad, sino dilucidar si en ese tipo de simultaneidades estaríamos adquiriendo un conocimiento válido de la condición humana a priori, o bien si la contradicción identificada (mediante predicados que contradicen los conceptos) necesariamente lo anula. Si ocurre lo segundo es cuando quedaríamos trabados, es decir, no estaríamos accediendo a ninguna verdad absoluta (o analítica) y habría que rendirse a que la condición universal para conocer al Otro empíricamente es una cuestión relativa, obscura, problemática y ambigua, en la que cada cual (gobiernos, partidos, iglesia, escuela y sujetos individuales) puede elegir la estrategia que mejor le venga en cada coyuntura (esta sería la síntesis Baumaniana).

Las causas culturales de este fenómeno práctico se explican perfectamente con la crítica de Freud sobre los imperativos éticos de los mandamientos (tomados por imposibles para nuestra psique ${ }^{21}$ ). A la

21. Freud deslumbra sin escrúpulos la mirada compasiva cuando expone que "el mandamiento «Ama a tu prójimo como a ti mismo» es la más fuerte defensa en contra de la agresión humana, y un destacado ejemplo del proceder apsicológico del superyó de la cultura. El mandato es incumplible; una inflación tan grandiosa del amor no puede tener otro efecto que rebajar su valor, no el de limitar el apremio. La cultura 
descuida todo eso; solo amonesta: mientras más difícil la obediencia al precepto, más meritorio es obedecerlo. Pero en la cultura de nuestros dias, quien lo hace suyo se pone en desventaja respeto de quienes lo ignoran (...) La ética llamada «natural» no tiene nada para ofrecer aqui, como no sea la satisfacción narcisista de tener derecho a considerarse mejor que los demás". Freud, Sigmund. Obras completas. Volumen 21 (1927-31) Amorrortu, Buenos Aires, 1976, p. 138. Para entender mejor la causa por la que Freud nos alarma de este modo en "El malestar de la cultura", es revelador citar el comentario de Lacan en su Seminario 7, cuando analiza el origen del "horror" que provoca que el sujeto se eche atrás a la hora de amar al otro como a él mismo: “¿Ante qué retrocedemos? (...) Retrocedemos ante el atentar contra la imagen del otro porque es la imagen sobre la cual nos hemos formado como yo. Ese prójimo tiene precisamente sin duda toda esa maldad de la que habla Freud, pero que no es otra que la misma ante la cual retrocedo en mí mismo, y que amarlo es verdaderamente amarlo como un mí mismo, pero al mismo tiempo es necesariamente aproximarme a cierta crueldad; la suya o la mía, me objetarán, pero todo lo que acabo de explicarles es justamente para mostrarles que nada dice aquí que sean distintas. Parece más bien que fuera la misma, con la condición de que sean atravesados los limites que me hacen plantearme frente al otro como mi semejante" (pp. 119-122). En mi forma de analizarlo, el nexo entre el horror que bloquea el avance hacia el amor al prójimo, y el grueso desgarramiento que sufre la posibilidad de una ética para la vida, que refleja el núcleo cultural de lo que angustia a Bauman, lo localizo en la consolidación posmoderna de la creencia de que uno mismo, para ser útil para la sociedad (y obtener su protección), debe dejar de cuestionarse a sí mismo (y con ello, tal y como sugiere Bauman en varios momentos de su obra, el ciudadano productivo -que trabaja, vota y disfruta del consumo- olvida el desafío eterno de mejorarse a si mismo ante un ideario ético). En consecuencia, mi argumento es que el salto dialéctico que implica amar al otro, concebido este goce del prójimo como un espejo en cuyo trasfondo aguardan los mismos miedos, deterioros y deseos maliciosos que uno mismo vez que desemboca en otro espaciamiento para el desarrollo productivo de la convivencia social: el espacio estético. Estaríamos así en un territorio donde al extraño se le deja deambular para que participe del espacio de la ciudad siempre y cuando la extrañeza que suscite para la conciencia de normalidad se considere que está bajo control $^{22}$. Tanto el inmigrante como el turista, si ocupan el lugar correcto, digamos que "su lugar", pues, "vigilado", formarán parte del espectáculo y entretenimiento del espacio urbano; esta sería una prueba de cómo dentro del espacio físico es "acogido" el espacio moral. Pero esta introducción de lo moral en lo estético va acompañada de una dinámica de distanciamiento, algo que se observa, por ejemplo, cuando los efectos materiales o externalidades de la gentrificación en sus diferentes modalidades (fachadas restauradas o aseadas, infraestructuras y mobiliarios renovados, apertura de comercios, ensanche de aceras, tráfico regulado, alquiler vacacional de viviendas, etcétera) son recibidos como estímulos sensoriales placenteros por los miembros de la comunidad que queda al margen del coste o de alguna posible lesión o perjuicio en su statu quo, momento este en el que el Otro (aquellos que son lesionados o expulsados) queda transmutado en lo extraño (en el inmigrante, el su-

aprisiona en su fantasma, solo podría producirse a partir de cuestionarme si la huida que práctico de mi semejante es plenamente lógica, pues, el Otro, como tal, es también una parte semejante de mí (y de mi unidad con el resto de la humanidad), lo que debería mostrarme su contrario, es decir, lo ilógico de haberme detenido, que a su vez se opondría al mecanismo irracional que encandila al Ello.

22. "Los extraños pueden disfrutarse únicamente si su extrañeza ya ha sido asegurada, si los espectadores la intuyen y tienen confianza de que la complacencia no representa ningún peligro". Op. cit., Bauman, p. 190. 
cio, el pobre y el groseramente débil para ser integrado en ese espacio), es decir, queda reducido a un organismo informe o "cuerpo ajeno" para la unidad de la que el resto sí que participa (basada en el deleite de percibir lo que está limpio, en orden, arreglado, progresado y que genera valor económico, equiparando las sensaciones recibidas con valores morales). Paradójicamente, fruto de la radicalidad moral que vehicula este choque perceptivo, emerge una dialéctica entre esa ajenidad y el encuentro de un deber:

La actitud moral, con su molesta proclividad a forjar sus propios grilletes en la forma de responsabilidad por el otro-que convierte al Otro de objeto de satisfacción en un Rostro exigente- es un enemigo declarado de la corriente, la esencia del espaciamiento estético. La actitud moral ata la atención a su objeto por más tiempo de lo que habría hecho si estuviera libre de ataduras: convierte la atención en una fuente de responsabilidad, y la responsabilidad involucra mantener la atención en tanto el Rostro la necesite. ${ }^{23}$

23. Bauman, ibidem., p. 206. Para comprender mejor esta proposición es interesante citar un comentario de la celebre escritora de literatura popular J.K. Rowling en la red social Twitter el pasado 16 de diciembre de 2019, haciéndose eco de un artículo de Nick Cohen en The Guardian, publicado en la misma fecha bajo el título "Why are Labour's leaders so quite on Europe? Maybe its the lure of disaster". El tweet de Rowling recogía el siguiente párrafo del texto original de Cohen: "Desear el sufrimiento a las personas que son más débiles y pobres que tú es repugnante y no es menos desagradable cuando Jeremy Corbin en lugar de Jacob Rees-Mogg está deseando que la miseria de los demás crezca para hacer avanzar su programa político". El artículo completo de Cohen es un ataque directo a Corbin, al que acusa de ser un ortodoxo leninista, dando por hecho que el ala radical del partido laborista (que según Cohen es la que domina las decisiones que toma Corbin) espera con ilusión que el Brexit haga colapsar la sociedad y la economía de Gran
En la apelación "libre de ataduras" es donde se encuentra el quid político de nuestro tiempo, en cuanto a lo que un acto moral significa y la demanda que este ejerce sobre nuestra conciencia social. Desde lo cual, Bauman destila dos consideraciones decisivas:

i. El acto moral se ha tintado (naturalizado) de ambivalencia ${ }^{24}$, concebido

Bretaña y gracias a ello llegar al poder del estado e implantar una "vacía utopía socialista". Al argumentar su hipótesis describe abreviadamente el pensamiento de Lenin, como la idea referida a la ventaja que otorga esperar a que una nación sea derrotada por algún enemigo para, aprovechando el caos resultante, implantar un proceso revolucionario. Cohen desacredita la causalidad de la dialéctica defendida por Lenin al contraponerle que los colapsos económicos más disruptivos siempre han provocado el advenimiento de dictaduras fascistas o el acceso al poder de la derecha más conservadora. No entraré en criticar las intenciones, omisiones y aporías evidentes de la lógica política que practica Cohen. Lo que me interesa es el proceso cognitivo que precipita que Rowling, haciendo suyas las ideas de Cohen, al mismo tiempo que reconoce la existencia de los pobres, marginados y débiles, niegue la posibilidad moral e histórica de eliminar esa situación mediante un programa socialista. De manera que la exigencia del Rostro hacia su responsabilidad individual logra amortiguarla al demostrar para sí misma que no hay una alternativa política con valor moral, luego su responsabilidad (que simplemente se materializaría en no votar al partido laborista, lo que se traduce, probablemente, en salvarse de gravámenes fiscales que reduzcan su patrimonio) queda involucrada con la situación del Otro, aunque sobre dicha situación, de consciente sufrimiento para quien observa, no contribuya a cambiarla ni eliminarla (porque, a tenor de la alineación, no puede serlo, habilitándose así la distensión psíquica).

24. "En la compleja red de dependencias mutuas, las consecuencias de cualquier acto forzosamente son ambivalentes; ningún acto, por más noble y desinteresado que sea -y beneficioso para algunos-, puede salvarse verdaderamente 
como un algoritmo desacralizado cuyo fin (si fuera universal) es hacer posible la realización individual (el placer que culturalmente está autorizado), permutado en un cálculo de posibilidades para multiplicar las ganancias y minimizar las pérdidas de la vida (estableciendo antinomias aceptadas, naturalmente, como racionalmente inevitables: reconocimiento versus vergüenza, sacrificio versus satisfacción). El Mandamiento judeocristiano queda sancionado como un "reino" fuera de la realidad histórica; inalcanzable (sublimado como un

de herir a quienes se encuentran, inadvertidamente, del lado receptor". Ibidem., p. 207. Esta ambivalencia también es el resultado de la caída del proyecto de contener la conducta ética del hombre en un régimen normativo incuestionable, perfectamente medido y comprobado para toda situación. Bauman revisa la escuela intuicionista liderada por G. E. Moore (tendente al enunciado de que "lo bueno es evidente" y no necesita de explicación ni concepto que lo delimite, pues, su comprensión se compone de ejemplos concebidos como posibilidades sensuales, ya sea el "afecto personal" o la "apreciación de lo bello") pero no para prescribirla como superior sino para hallar un lugar, el que él quiere ocupar, que equivalga a un entendimiento racional, histórico y críticamente intermedio, pues, que no niegue ni renuncie a ninguna de las dos perspectivas, ni la universalista ni la personal, aunque enfatizando, eso sí, un escepticismo necesario (la inteligencia del número que veneraba Kant) para contrastar la fuerza de la opinión unánime que "de ninguna manera es garantía de su valor ético". Por tanto, a su parecer, mediado por su memoria del Holocausto, “(...) no hay contradicción entre el rechazo a la ética de las normas de convención social fundamentadas racionalmente, y la insistencia de que sí importa, y tiene importancia moral, lo que hacemos y de lo que desistimos". La conclusión es armar al sujeto con una puerta para el entendimiento (la propia conciencia concebida como la responsabilidad moral que es personal e inalienable) como garantía para "desobedecer la orden de hacer el mal”. Ibidem., p. 292. "lujo" idealista) para la felicidad real (la cual es experimentable en la escala que solo es posible recrear).

ii. La adiaforización social emerge como una isla cognitiva o espacio de atención reducido y condicionado para relacionarse sincopadamente con el Otro (lo que supone no tener que asumir el coste por no cumplir con los compromisos hacia él). La acción moral se fragmenta en resultados esperables, pero tanto la intención como el efecto final del acto adquieren una significación neutral y, si cabe, inapreciable para merecer el elogio o el rechazo (el contacto con lo extraño tiene lugar, pese a que el diálogo se posponga o se diluya en un discurso colmado de buenos deseos). Esto es justamente lo que implanta la adiaforizacion: el permiso (culturalmente institucionalizado) para la rendición al hecho de que la persona "no puede derrotar la ambivalencia, solo aprender a vivir con ella" 25 .

Consecuentemente, el cierre del sujeto se produce como un empujón deliberado ("nudge") para escapar del deber (y saltar a otro deber más fácil de satisfacer), y con ello poder sobrevivir a la presión de las fuerzas inconmensurables que cincelan y someten el curso de la vida material. El "fracaso" moral que es identificado (la inacción ante la persistencia de pobres, de personas sin vivienda, de trabajadores precarios sin cualificación ni prestaciones sociales, la denegación de permisos de residencia a los inmigrantes, el descenso de los ciudadanos en la escalera social por pérdidas de empleo, renta y endeudamiento; todos estos fenómenos precipitan en la conciencia de cada individuo la urgencia de un aprendizaje práctico para

25. Ibidem., p. 208. 
huir -y a cualquier precio mantenerse alejado- del espacio que ocupan los pacientes del "fracaso") en verdad no genera reflexión ni inflexión para impulsar una transformación social que se oponga a la creencia de que aquello de lo que se compone son procesos inevitables (aunque su presencia exprese el reconocimiento de la impotencia del sujeto moral en nuestra sociedad). En realidad, el "fracaso", como significante, es obliterado (neutralizado), dado que se teje el consenso social de que la dificultad que entraña la obligación de vivir productivamente en el mundo moderno impide la razonable realización de dicho sujeto moral.

Así es como Bauman conduce su investigación sobre la vigencia (mutilada) del cuerpo social hasta capturar un cambio de situación: "el paso de la modernidad sólida o pesada a la (posmodernidad) ligera o licuada"26. Por tanto, dicho cambio, vinculado a la evolución de la estructura productiva y de la relación entre capital y trabajo, tiene su transposición en las manifestaciones morales y de amor que son establecidas con el Otro, así como en los mecanismos

26. Bauman categoriza dos fases: (i) La fase pesada (o sólida) basada en el "compromiso entre capital y trabajo fortalecido por el carácter mutuo de su dependencia". (ii) La fase ligera (licuada o líquida) la vincula con la mentalidad de a corto plazo, sustentada en la sustitución de la alegoría productiva de "hasta que la muerte nos separe" o dicho por él de otro modo: "los miembros de la pareja ya no esperan estar mucho tiempo en compañía del otro". Los "inputs" o salidas de este cambio histórico de mentalidad cultural desembocan en los enunciados (recibidos como demandas para la represión del sujeto) relativos a nociones vagas y desplazadas de sus marcos lingüísticos y científicos originales como la flexibilidad y la resiliencia, señaladas para absorber las necesidades del mercado, la empresa y el compañero de vida. Ver Bauman, Zygmunt. La sociedad individualizada. Cátedra, Madrid, 2001, pp. 32-40. de ayuda y protección que el Estado asume y gestiona hacia este. He ahí el modo, recorrido una y otra vez por el peregrinaje de la conciencia del sujeto, que es utilizado para recibir la absolución, es decir, para reproducir el límite del amor hacia los demás en base a las necesidades de la razón y el "sentido común" (que determinan el alcance de la recaudación fiscal y el dimensionamiento de los presupuestos estatales para sufragar servicios públicos, pensiones y subsidios); ambos son retorcidos en artefactos ideologizados para expiar la culpa por el fracaso de la no salvación de los "rostros" del prójimo (la situación sembrada y creída de que "no podemos permitírnoslo"27 definitivamente es abrazada).

La salida a la luz para dejar atrás tanta niebla y polvo nos la señala Bauman en la dirección ascendente de unos eslabones ilusionantes, fronterizos con un espacio en el que el espíritu trascendente y el inconsciente político se llenan el uno al otro, que le marcan, compuestos por las huellas de Emmanuel Levinas y Vladimir Jankélévitch. En uno de los extremos del anillo que forman estos eslabones entre sí, pues, subido primero en el discurso de Levinas, Bauman, sentencia que el Estado (concebido desde el ideologema liberal que vertebra la cultura dominante) es un mecanismo de violencia que

27. "Podríamos ayudarlos, a todos alegremente, pero esto no es posible sin repartir nuestra riqueza, sin unos impuestos más altos, y esto sería perjudicial o estúpido (...) Puede que sea triste y deprimente no poder guiarse por los sentimientos, pero el amor necesita a la razón para que lo salve de su necedad". Ibidem., p. 198. La ironía es aclarada para evitar malas vibraciones: "Lo que sostengo es que estas son utilizaciones indebidas de la razón. Ofrecen una escapatoria de una difícil situación moral, no la ocasión para hacer frente a sus verdaderos dilemas y tratar de resolverlos ". Ídem. 
ejecuta divisiones (lo real queda organizado en clases y categorías) y delimita el amor a los demás, es decir, administra la "misericordia" que discurrirá entre leyes y costumbres mediada por el lenguaje de la justicia, y proporciona un espacio ontológico al hecho de que en sí la justicia nunca es definitiva, sino que siempre se podrá alcanzar una "justicia más justa" (lo que implica una contradicción lógica y las consecuentes pérdidas de eficacia racional al aplicarse desde una concepción tan sesgada). El despertar del olvido ético queda resumido en el siguiente hallazgo:

La justicia que el Estado administra nace de la caridad gestada y criada dentro de la situación ética primaria. $Y$, sin embargo, la justicia solo puede ser administrada si nunca deja de verse empujada por su impulso motor original; si se conoce a sí misma como la persecución interminable de una meta siempre elusiva, la re-creación entre individuosciudadanos de esa singularidad del signo de nacimiento del Otro como Rostro. ${ }^{28}$

Bauman continúa concretando que el escenario primordial de la ética es el de la justicia social o, dicho con otras palabras, el mundo social es a la vez "vástago

28. Ibidem, p. 205. La inclinación de un Estado hacia la justicia dimana del excedente de compasión que tiene su fuente primaria que no es otra que la propia conducta ética de los sujetos que están bajo su amparo (más allá de la cultura explícita, anda depositada en las raíces implícitas de esta misma un artefacto de conjunción entre el inconsciente y el desarrollo teorético mediante el cual se inmuniza el despertar al Otro en la conciencia de cada uno sin caer en falsificaciones (mi cuidado de él, y su propia preocupación de mi exentas de intereses egoístas y de puntos ciegos o de indiferencia). En consecuencia, el Estado no debe ser más que el espejo que da testimonio del "peso" que tiene ese excedente (la transferencia de la responsabilidad infinita a los hechos "impuros"). legítimo y distorsión del mundo moral"29. Mientras que en el otro extremo de la conjunción del anillo lo que prima es la disquisición de Jankélévitch sobre el sentido de lo impuro como signo equilibrado de la humanidad esencial. De modo que lo asimétrico, imperfecto, delicado e inconstante, lo que no genera la disyunción sino una mezcla, pues, ese ser impuro es lo que permite el conocimiento de uno y del Otro, enalteciendo que "quien no es ni lo uno ni lo otro, es por ello mismo uno y otro"30. Una forma de afirmar que el hombre no podrá dejar de ser un conflicto $^{31}$ entre la positividad (optimismo) y

29. Para Levinas, la responsabilidad ética del individuo no tiene límites sociales o normativos, de un modo u otro, ajustándose a la esencia hebrea, cada uno es infinitamente responsable: “(...) un ser humano que realmente merezca ese nombre en su sentido europeo, derivado de los griegos y la Biblia, es un ser humano que considera la santidad como el valor último, un valor inalcanzable". Ibidem., p. 207. La santidad aludida queda sustentada en la preocupación por el prójimo por delante de la de uno mismo no por alienación, sino por elección, no por la determinación de un concepto a priori y, en cambio, sí por una pasión (aunque esta sea rechazada en un instante) de responsabilidad (a mi pesar) por el Rostro. La santidad es el núcleo que cura la indiferencia hacia el Otro "al margen de todo cálculo y de todo posible agradecimiento". Ver Chalier, Chaherine. La huella del infinito. Emmnauel Levinas y la fuente hebrea. Herder, Barcelona, 2004, pp. 232-235.

30. Jankélévitch, Vladimir. Lo puro y lo impuro. Taurus. Madrid, 1990, p. 10.

31. La expresión con la que designa el desacuerdo (el "conflicto") quedaría ilustrada por Jankélévitch en su alusión al autorretrato literario del duque La Rochefoucauld: “(...) podría servir de ilustración al fragmento de Pascal sobre la naturaleza intermedia del hombre. El pintor que se representa lúcidamente con sus verrugas, pequeños defectos y reproduce las disimetrías de su rostro, expresa en su lenguaje la verdad de una condición híbrida en la que el mal convive con el 
la negatividad (malicia) a partir de lo cual la pureza "vacía" (pues la que no es así únicamente le correspondería a Dios) se demuestra como una construcción ideológica preparada para separar al hombre de sus semejantes.

Bauman, en su desarrollo teórico se moviliza como un receptáculo de estos dos eslabones de pensamiento, articulando una comarca de reunificación entre, primero, la indagación de un espacio ético donde quede superada la desunión del ideal espiritual con respecto a la vida material y sensual, quedando ambos intricadamente asociados y comprometidos. Y, segundo, de la catarsis que viene detonada por la interacción de la conducta del sujeto con la presencia del Otro (y la práctica de un diálogo oculto con el inconscien-

bien que nos desea en una zona intermedia entre el optimismo y la misantropía". Ibidem., p. 11. La doble negación del eslabonamiento adverbial "ni, ni" nos dirige hacia un contraste de opuestos de gran relevancia para nuestra conciencia. Por consiguiente, el núcleo significativo susceptible de adherirse a la argumentación moral que estamos desarrollando radicaría en que la contaminación que nos sobreviene por medio del Otro es, con exactitud, la que nos encamina positivamente hacia el proceso de "purificación" (descubierto como el destino escatológico para otra realidad significante, equivalente a un proyecto común para la humanidad como unidad y totalidad): " $E n$ todo el género humano, como en toda la humanidad, nadie es puro, jamás lo ha sido ni nunca lo será, nadie, ni siquiera un santo, nadie y ni siquiera por milagro, y, a pesar de todo, el deseo de pureza alza obstinadamente su protesta en nosotros contra los fracasos, los desmentidos y las decepciones de la experiencia". Ídem., p. 22. ¿Acaso no es dicha "protesta", la exigencia de pureza, la misma que vivifica el juicio racional de los votantes de izquierdas a la hora de retirarse del compromiso y la esperanza depositados en los partidos que históricamente les han representado, sustanciada (la protesta) en el incumplimiento reincidente de las obligaciones éticas? te reprimido de ambos rostros), precipitando que lo que fue una vez simple sea transformado en un enunciado complejo, denso y alterado (apareciendo la angustia por la alteración). Gracias a ello emerge el desdoblamiento del sujeto (no su fragmentación sino su enriquecimiento al introducirse en el discurso del Otro), desde el cual, el sacrificio por el entendimiento de la responsabilidad hacia los demás ${ }^{32}$ puede existir.

\section{El pobre de vida eterna}

Los "hombres pobres", como el motor de la fantasía con la que los ebionitas propagaron el cristianismo por el Norte de África y Oriente Medio durante los primeros siglos de nuestra era (usado como expresión simbólica de una transformación social cuya meta teleológica se circunscribía a la espera de otro mundo), como es fácilmente reconocible, ha ido sufriendo

32. "El sacrificio es el acercamiento a aquel de quien se es responsable". Ver Levinas, Emmanuel. De otro modo que ser, o más allá de la esencia. Sígueme, Salamanca, 1987, p. 190. Ejemplifico este "sacrificio" con la conducta de Cleo, la tata protagonista del filme "Roma" de Alfonso Cuarón (2018), quién en la superación del dolor por la pérdida de su bebé, muerto en el parto, arriesga su vida salvando de que se ahoguen en una playa a los hijos de su patrona (aunque ella misma, Cleo, en realidad, no supiera nadar). La familia que es salvada le devuelve moralmente el amor recibido (la causa indicada, la del acercamiento recíproco, es de donde va generándose el excedente de misericordia), y aunque no sea declarada políticamente la extinción de la diferencia de clases (la relación entre ama y esclava no se supera), lo que sí se enfatiza en el discurso del filme es la igualación, como parte del Otro, entre ambos sujetos en cuanto al sacrifico que, como mujeres (abandonadas por los hombres), asumen hacia sus hijos (y los hijos de los demás). 
una abrupta transliteración, mediada, en última instancia, por la ética del trabajo moderna ${ }^{33}$, perfectamente codificada por la lógica cultural del capital, y con el consiguiente adueñamiento de un lenguaje particular, mítico y así fuertemente político desde el cual regular la evolución psicosocial de la mentalidad predominante en el seno de las sociedades contemporáneas. Por consiguiente, hace tiempo que nadie quiere ser un "hombre pobre", pues en el hecho de serlo ya no se reconoce huella alguna de una vía hacia la redención o iluminación, ni de una puerta intermedia hacia una revolución social. Aquel mensaje de movilización, y a la vez de burla, con reminiscencias comunistas, trasladado a la boca de Jesús por el evangelista de

33. Bauman describe la ética del trabajo anterior a su fase de adiaforización como "la fórmula para que ambos grupos (trabajadores y empresarios) hicieran coincidir sus intereses", y cuya síntesis quedaba resumida en la creencia de que "el trabajo era el camino que, al mismo tiempo, podía crear la riqueza de las naciones y acabar con la pobreza de los individuos". Efectivamente, la "apología del trabajo" derivó de las necesidades industriales del siglo XIX hasta que, progresivamente, se fue creando la disyunción definitiva entre crecimiento económico y crecimiento en el empleo (al cabo de décadas de perfeccionamiento técnico y distribución acumulativa de la riqueza ya no fueron necesarios tantos trabajadores. Las tecnologías de automatización y la racionalización de la producción adecuaron aquello de que "el aumento de la mano de obra limita la productivi$d a d$ ', lo cual fue alzado, por delante de cualquier noción sobre la creación de valor, como un precepto central para cumplir con el fin de la economía. Se puede admitir que, de un modo simple, refleja el momento posindustrial en el que las relaciones de trabajo fueron desarrollándose desde el siglo XX hasta la actualidad. Ver: Bauman, Zygmunt. Trabajo, consumismo y nuevos pobres. Gedisa, Barcelona, 2003, pp. 99 y 102.
Mateo $(19,24)^{34}$ ha quedado sublimado durante los últimos ciento cincuenta años a través de la existencia de una clase trabajadora u "obrera" que, poco a poco, no solamente fue tratando de diferenciarse de otra clase inferior o "baja" así como de rescindir cualquier lazo en común con la de los marginados, sino que, después, en el desarrollo posmoderno, recibió la pretensión de dejar de serlo (o ser no obrera) para ocupar un nuevo espacio de privilegios reformulados o expandidos dentro del concepto sociológico falsamente elástico e igualmente alienante de clase "media". Bauman aclara del siguiente modo cuál es el hilo conductor de este vocabulario:

La expresión "clase obrera" evoca la imagen de una clase de personas que desempeña un determinado papel en la sociedad, que

34. Recuerdo el versículo aludido que a su vez parafrasea un enunciado del Talmud: " $Y$ os digo de nuevo: es más fácil para un camello pasar por el ojo de una aguja que para un rico entrar en el reino de Dios". Fue Georg Brandes quien argumentó en su celebre obra "El mito de Jesús" (Crítica Literaria, Madrid, 2010) la inspiración permanente que los autores de los Evangelios toman del Antiguo Testamento y del Talmud, hasta el punto de que prácticamente la totalidad de los acontecimientos y testimonios narrados en aquellos vienen a ser adaptaciones o extrapolaciones de sucesos, profecías y discursos recogidos en estos últimos (p. 89), reduciéndose al mínimo las posibilidades de que fueran hechos históricos síncronos con la vida de quiénes los escribieron (fueran quienes fueran). Curiosamente, el proceso de neutralización de los objetivos compartidos entre las clases antagónicas a través de la ética del trabajo viene a ser el negativo de su fuente primera, es decir, una deformación en absoluto innovadora ni progresiva de las raíces que originariamente nutrieron el proceso múltiple (político, científico y artístico) mediante el cual se implantó la fe en el capitalismo como motor legítimo del crecimiento económico y civilizatorio (una "fe" cuajada mediante un desplazamiento ideológico de los significados implícitos). 
hace una aportación útil al conjunto de ella y, por lo tanto, espera una retribución. El término "clase baja" reconoce la movilidad de una sociedad donde la gente esta en continuo movimiento donde cada posición es momentánea (...) Hablar de "clase baja" es evocar a personas arrojadas al nivel más bajo de una escala pero que todavía pueden subir (...) En cambio, la expresión clase marginada corresponde ya a una sociedad que ha dejado de ser integral (...) es una categoría de personas que está por debajo de las clases, fuera de toda jerarquía, sin oportunidad ni siquiera necesidad de ser readmitida en la sociedad organizada. ${ }^{35}$

En primer lugar, aplicando el prisma del materialismo dialéctico, la clase obrera, abastecida en nuestro tiempo por, esencialmente, los trabajadores industriales y de servicios, han pasado a ser estratificados según su acceso a los medios de consumo, unido a la relación que dicho nivel de consumo encadena con su posición en la jerarquía ocupacional. Una relación mediada por una serie de factores como las retenciones fiscales que aporta cada miembro al Estado (en las relaciones sociales, el porcentaje de IRPF se ha convertido en un signo lingüístico que más allá de su función matemática también es utilizado para designar o estratificar el lugar que ocupa un sujeto en la escala del éxito social), el nivel de estudios realizados, la práctica profesional alineada con la vocación desarrollada ${ }^{36}$, y la adaptación

\section{Ibidem., Bauman, p. 103.}

36. Bauman expone el artefacto de la "vocación" como otra distorsión de la ética del trabajo de nuestro tiempo. La evolución de esta ha precipitado que se haya perdido la concepción igualitarista de la que partió, en el sentido de que cualquier tipo de trabajo, fuera más o menos cualificado, penoso o alienante, dignificaba a la persona. Sin embargo, el advenimiento del consumismo ha introducido un factor de disrupción, esto es, la a los criterios subjetivos que desde el Superyo y la superestructura son postulados y vigilados en el desempeño productivo y cívico individual para que cada cual sea adscrito a cada clase, susceptible así de recibir un tipo de protección y reconocimiento (que se resume en el deseo de los demás y del propio Estado de ser ese yo).

Fruto de este deslizamiento político y cultural abanderado por la doctrina del liberalismo durante la segunda mitad del siglo pasado, se ha finalizado el velado de la lucha estructural entre las clases sociales, dirigiendo el foco cognitivo hacia una fantasía mítica que Stanley Aronowitz describe como un reemplazo de la materialidad de las estructuras sociales por la del lenguaje y los textos (sustantivizados, por ejemplo, en los mensajes que son distribuidos por los medios de comunicación, gobiernos, empresas e individuos

importancia del valor estético contenida en la propia experiencia del trabajo (ese "estético" se convierte en un acelerador de la diferenciación identitaria, el individualismo y el estatus social). De modo que "se exige que las profesiones elevadas (las que entran en el exclusivo club de las que crean vocación o que tienen sentido "trascendente") tengan las misma cualidades necesaria para apreciar el arte: buen gusto, refinamiento, criterio, dedicación desinteresada y una vasta educación. Otros trabajos son considerados tan viles y despreciables que no se los concibe como actividades dignas de ser elegidas voluntariamente. Es posible realizar estos trabajos solo por necesidad (...)". El valor estético de las profesiones elevadas o de las pseudoprofesiones que la cultura de consumo legitima como altamente productivas (véase el caso de modelos de publicidad, actores, periodistas y gente VIP que han profesionalizado su tiempo de trabajo vendiendo productos gracias a subir sus fotos tomadas de su vida personal a sus redes sociales) han terminado por "elevar el trabajo mismo a la categoría de entretenimiento supremo y más satisfactorio que cualquier otra actividad". Ibidem., p. 59. 
cosificados en mercancía a través de las redes sociales alojadas en Internet o en las aplicaciones de los teléfonos móviles), pues, reafirmándose una materialidad narrativa ${ }^{37}$ alejada, por la razón de ser de

37. Para Aronowitz, la consecuencia de que las diferencias sociales hayan sido extirpadas de la categoría dialéctica de clase (a lo que añadiría que la explicaciones de dichas diferencias están siendo desplazadas hacia otras narrativas como la de igualdad de género, diversidad étnica y cultural o sobre cuestiones raciales), consistiría en el fenómeno de que la estructura de la sociedad solamente sea concebida y asimilada como un ascenso unidireccional y verticalizado, depositándose el permiso de las reglas de organización bajo el gobierno ilimitado de una concepción jerárquica de carácter antigravitatorio o de siempre de arriba hacia abajo. Dicho de otro modo, la expectativa legítima de transformar democráticamente la estructura social desde sus capas inferiores cada vez está más sofocada (y no digamos la esperanza de eliminar las clases sociales como los signos ideológicos de una desigualdad naturalizada cuando estas mismas han sido vetadas como actores políticos legítimos). El diagnóstico sobre el desfallecimiento ético que leemos en Bauman se solapa con los efectos esperables de la negación de la lucha de clases que identifica Aronowitz: "Las prácticas de clase dejan sedimentos materiales en los procesos laborales, en las instituciones, en la vida cotidiana y en el lenguaje vernáculo, incluso cuando los objetivos de los actores políticos no se cumplen plenamente o no se manifiestan como formas vivas de conflictos sociales y políticos. Y estas prácticas a menudo contradicen las creencias y normas de los actores. En resumen, nos referimos a lo que decimos, pero a veces nuestras acciones hablan con una voz diferente de nuestra voz moral". Véase Aronowitz, Stanley. How Class Works. Power and Social Movement. Yale University Press, New Haven, 2003, pp. 7-9. Desde mi punto de vista, la imagen que se proyecta en el inconsciente político, la de vivir en una sociedad "estática" en la que las instituciones que regulan el ascenso social existen al margen o cada vez más alejadas de las necesidades de la base, provoca que esta última ya no desee alcanzar la "cima" como reto principal para este mismo concepto, del análisis racional basado en datos y remisa a la iniciativa de indagar en los porqués de los acontecimientos, lo que finalmente hace vacía la realidad social que es pensada. Una consecuencia de este vaciamiento es que los miembros de cada clase en conflicto ya no perciben los condicionamientos de su vida como el efecto de una relación antagónica a partir de la cual queda estructurada la sociedad, la economía y el resto de instituciones que vertebran el Estado. Esta negación desemboca en un aumento de las creencias sustentadas en discursos instrumentales que sintonizan con los deseos reprimidos (incluidos los no civilizatorios) y que una vez lo traicionan en la práctica (lo que será denunciado por el siguiente discurso para su propio provecho), es este fracaso el que posibilita que afloren nuevos textos igualmente alienantes.

En segundo lugar, el análisis de la etnología de los marginados que realiza Bauman $^{38}$ concluye sin tapujos que todos aquellos que reciben la marca de serlo pasan a compartir un rasgo esencial:

la vida (ni sentirse responsable o culpable por no conseguirlo), sino que opte por una radicalización de la protesta y una exigencia paradójica e irracional de soluciones antidemocráticas que acaben con la mínima posibilidad de corregir la injusticia social incrustada en el orden establecido (el deseo hacia el colapso y la pulsión de muerte son cada vez más evidentes entre perfiles empobrecidos o desencantados que voluntariamente deciden seguir programas políticos contrarios a sus intereses históricos de clase; a menudo mimetizando un estado letárgico y autista).

38. Apoyada por la descripción de Herbert J. Gans en "The War against the Poor: The Underclass and Antipoverty Policy". Basic Books, New York, p. 2: incluye a los "fracasados" escolares, mujeres sin recursos con hijos fuera del matrimonio, drogodependientes, desempleados de larga duración, mendigos, delincuentes y personas que duermen en la calle. 
(...) los demás no encuentran razón para que existan; posiblemente imaginen que estarían mejor si ellos no existieran. Se arroja a la gente a la marginalidad porque se la considera definitivamente inútil, algo sin 10 cual todos los demás viviríamos sin problemas (...) Todos nos beneficiaríamos si desaparecieran. ${ }^{39}$

Partiendo de esta proposición se puede inferir tanto que la sola presencia de los marginados atenta tanto contra el goce estético de la "nueva" ética del trabajo, como que, al mismo tiempo, incorpora para la conciencia de los bienaventurados de la clase "trascendente" (y los que aspiran a integrarse en ella) una liberación de la responsabilidad hacia la fragilidad de los hombres ${ }^{40}$ (mientras que los que quedan atrapados en el desencanto cruel o en el horror giran su insatisfacción hacia dicha fragilidad en forma de odio y violencia hacia todo, especialmente ellos mismos). Esta retirada del sujeto ante la

39. Ibidem., Jameson, p. 104.

40. Levinas nos ilumina esa disconformidad estética mediante una lúcida reflexión acerca de la producción del arte: "Nos vengamos de la maldad produciendo su caricatura, que le quita la realidad sin aniquilarla; se conjuran las malas potencias llenando el mundo de ídolos que tienen bocas, pero que no hablan". Levinas, de fondo, hila que todas las formas de entretenimiento (y aquí podríamos incluir los informativos televisivos cuando, en ocasiones, recogen las desgracias de los marginados en imágenes) son elementos adoptados por el sujeto para acceder a la evasión del mundo, pero con su simple contemplación solamente cabe una interpretación: recibirlas como un signo de la vergüenza o, dicho de otro modo, parafraseándole, asistimos a la presencia de la maldad que surge de festejar la vida por algunos cuando reina la peste entre los demás. Véase Levinas, Emmanuel. La realidad y su sombra: libertad y mandatos, trascendencia y altura. Trotta, Madrid, 2001, pp. 123-150. También véase op. cit., Chalier, p. 205 y siguientes. debilidad del que es un objeto marginal con respecto a él (el pobre) queda asistida por una ética corruptora que habilita a que aquellas personas que no pasan la prueba de suficiencia (que pacta el Estado con el mercado) sean postergadas del mecanismo de reconocimiento del Otro e incluso aniquiladas de la conciencia colectiva: invisibles o bien culpabilizadas pues son "ellas las que se situaron, por propia elección, al margen de toda obligación moral", es decir, la sociedad (compuesta únicamente por los que no son marginados) no siente el deber insobornable de preocuparse por ellos e incluso experimenta asco ante la demanda de solidaridad que la miseria, el dolor y la humillación del prójimo contagian por las esquinas de las calles de las ciudades ricas, forzando a que tenga lugar la expulsión cognitiva para frenar la distorsión espacial. Ese "asco", como el manto misántropo que precede a la acción inmoral, queda bajo un proceso de saneamiento fruto de adiaforizar sus consecuencias. Por tanto, la moral (que venera la sociedad) no lo alcanza. Toda esta coyuntura, que está institucionalizada, desemboca en dos dinámicas que operan en el nivel mnémico de la evolución cultural y política de nuestras sociedades:

\section{i. El (nuevo ${ }^{41}$ ) pobre debe ser eliminado para gozar del orden ${ }^{42}$. Por lo tanto,}

41. Encajado dentro de la "nueva" ética del trabajo que articula el concepto de marginado como aquel que se expulsa por convicción de una función de utilidad para la sociedad.

42. Bauman lo descompone en dos ejes: (i) El eje de la capacidad de elección en permanente conflicto psíquico entre la pulsión de controlar el caos y la incertidumbre; lo que provoca la "resistencia a aceptar la vida en sociedad con todas sus impurezas"; y, al mismo tiempo, tal impulso misántropo colisiona con la propia necesidad del ser humano de siempre desear elegir, lo que incu- 
rre en procurar cambios y modificaciones que por lógica impactan sobre el curso del orden. (ii) El eje del establecimiento de normas para tener un referente seguro, esto es: "nos dicen qué es portarse bien en una sociedad ordenada". La norma es lo normal, y quien se desvía de la norma se convierte en un exponente de lo "anormal". Véase Ibidem., Bauman. pp. 130-132. Desde mi experiencia, ambos ejes son perfectamente observables en la mentalidad de perfiles de la clase "trascendente" adscritos ideológicamente a programas de conservación del estado actual de la sociedad. Lo ejemplifico del siguiente modo: una persona (útil y reconocida por la sociedad) que equipara exactamente los sujetos políticos del comunismo y del fascismo (reducidos a modelos revolucionarios del statu quo), y que como salida propugna sistemas de estabilización del orden que sirvan para garantizar su libertad y evitar la inflexión revolucionaria que tanto teme, en realidad, también está de acuerdo con reducir al máximo el número de elecciones que conserva, optando por un universo inflacionario de normas cuya función programática es la de fijar (y alterar) límites y estructurar categorías con las que la cultura de consumo y el Estado ejercen su dominio. Ahora bien, cuando la insatisfacción de este sujeto alcanza un punto de neurosis máximo, no resulta extraño que opte por aproximarse a un extremo revolucionario (indistintamente de cuál) con el que reencontrarse, en primera instancia, con su ansia de libertad (que suele relacionar con la capacidad de elección que le fue reprimida), para después, en un segundo momento o fase, autorizar otro modelo normativo, sumamente disciplinario si cabe, que vuelva a contener su ansiedad. Por supuesto, se observa en este movimiento que lo que el hombre pierde en la repetición de su renuncia a lo que significa el conocimiento de su libertad es en sí el propio hombre (pues, su naturaleza humana), de modo que agota su libertad por estar separado de su propio ser. Concibo la libertad (desde el perímetro de la tradición poshegeliana) como la necesidad que es perfecta y lúcidamente comprendida por mi ser $\mathrm{o}$, dicho con otras palabras, equivale a la superación de la alineación que determina mi conciencia. He ahí, por cierto, el simiente del hombre total y universalmente concreto soñado por Marx. Véase Cal- debido a que la uniformidad, la previsibilidad y la sostenibilidad son significantes ensalzados como virtudes naturales (designan nuevos significados relacionados con el bien social) que luego son gestionadas por los programas políticos (en los cuales acceden a un reconocimiento universal no sobre su contenido teórico sino sobre lo que exige su aplicación práctica), se deduce que hay molestas impurezas que deben ser borradas para que no atasquen la reproducción armónica de esas virtudes. La persistencia del pobre entra en la categoría de "barrera" para la consecución de la armonía del Estado, sin embargo, su eliminación en la práctica se posterga puesto que están presentes otras impurezas con las que hay que aprender a convivir; véase como la corrupción política, la especulación, la usura y los paraísos fiscales aunque sean relacionados con lo impuro y se dictaminen normas para corregirlas, ocurre que al mismo tiempo son admitidos como disfuncionalidades que genera el propio sistema (cuyo fin último no es garantizar la justicia social sino la democracia representativa como gestor delegado de la economía de mercado; la felicidad como destino de la humanidad es reforzada en este segundo fin, homologado como la puerta que es "realista" atravesar). Del discurso oficial, al final, lo que se sustancia es que el pobre, cuanto menos, quede pragmáticamente disimulado (alejado, confinado, con rostro pero sin voz propia, y lo suficientemente distraído para que no se asocie ni rebele contra su alienación).

vez, Jean-Yves. El pensamiento de Marx. Taurus, Madrid, 1964, p. 618. 
ii. El (nuevo) pobre, como el antiguo, es eterno, puesto que no puede ser eliminado completamente, quedando adscrito a la estructura de los factores inmanentes de la historia. Aunque es cierto que su razón de ser (su justificación teleológica) ha variado por completo. Bauman distingue el cambio de mentalidad en base a la periodización de transición premoderno versus moderno. De modo que, en el mundo premoderno, la existencia (y la misión) de los pobres adquiría un sesgo místico y redentor que era disfrutado por las clases más pudientes para expiar sus carencias morales ${ }^{43}$. Mientras que en la era moderna, el análisis racional provocó que los pobres dejaran de ser una cuestión de tradición (relativa al poder de lo muertos sobre los vivos y a la preparación de una vida mas allá de la terrenal), y se giraron en un "problema" de lógica que se debía solucionar para que el resto del discurso moral y económico pudiera ser mantenido en $\mathrm{pie}^{44}$. Es evidente que la lógica no obe-

43. "La presencia de los pobres era, por lo tanto, un regalo de Dios para todos los demás: una oportunidad para practicar el sacrificio, para vivir una vida virtuosa, arrepentirse de los pecados y ganar la bendición celestial. Se podría decir que una sociedad que buscara el sentido de la vida en la vida después de la muerte habría necesitado, de no contar con los pobres, inventar otro camino para la salvación personal de los más acomodados". Ibidem., Bauman, p. 134.

44. Varios aspectos definen la época moderna a este respecto: (i) "Los pobres representaron, desde entonces, una amenaza y un obstáculo para el orden; además desafiaron la norma". En concreto, la norma racionalista de ser productivos o culturalmente útiles. (ii) “(...) encontraron todo tipo de razones para quejarse y rebelarse contra los más afortunados, a los cuales empezaron a culpar por su privaciones. La antigua ética de la caridad cristiana pareció ya una carga intole- decía a un mandato ideal, neutral u objetivo, sino a la que exige el capital. Ahora, el pobre es pensado, recreado y calculado como el incómodo fantasma del Yo racional (aquel actúa como una figura alegórica de encarnación de la civilización hundida, provocando episodios psicóticos en los que se vivifican situaciones mnémicas generalmente inaccesibles a la conciencia).

En resumidas cuentas, la adiaforización con la que vivimos el mundo simultáneamente con y sin los pobres, (con la que Bauman enlaza ambas dinámicas), a mi modo de analizarlo, es otra determinación de la alineación. Adiaforización es pues una de las áreas en las que opera la alineación. Este último concepto implica que el sujeto humano se ha dado exteriormente un mundo neto y subjetivo de normas donde pesa, sobre todo lo demás, su carácter estético. Es ese mundo reificado quien ha velado o directamente ha inducido a que la sociedad rechace lo que en el mundo hay de verdadero y concreto. Claro está que tanto en el utillaje de Marx como en el de Bauman, el círculo de la alienación supone una tensión (o lucha) para que el sujeto recupere el entendimiento de su experiencia (aquel acto de descubrir lo oculto a fuerza de romper con el mandamiento que lo prohíbe que tanto emocionaba a Kipling ${ }^{45}$ ). Cuando

rable, una sangría para la riqueza de las naciones". (iii) Los pobres adquieren un nuevo perfil: aquel que ingenua o desesperadamente acepta su situación y afloja su voluntad para ya no salir de sus situación de marginación "inmune a las tentaciones del trabajo" y mansamente haciendo acopio de escasas necesidades para cubrir y sentirse "natural". Ibidem., p. 135.

45. El proyecto de transgresión en aras de descubrir la libertad que está contenido en el poema "El explorador" (1898) de Rudyard Kipling; con su célebre ruptura con el sentido común al 
Bauman fija la sentencia de la inmunidad a lo ético como el rasgo posmoderno que precipita la repetición eterna de la alienación ${ }^{46}$, queda determinada la imposibili-

resistirse a creer que "es absurdo ir más lejos, es el límite de la conservación"; nos conduce a su contrario (el opuesto a la convención social): la esperanza de que todavía hay un conocimiento perdido (no accesible en el presente) que puede ser recuperado y que nos purificará. Especulando sobre este poema una vez encajado en la imaginación de Bauman y Marx, quedaría claro que el despertar de la conciencia ética en el individuo no debe concebirse como un viaje de progresividad para el perfeccionamiento interno, de manera que en tal hipótesis se admitiría que gracias a todas las determinaciones exteriores se tendría como resultado que la humanidad definitivamente alcance la libertad total (verdadera). Al contrario, en sus respectivas utopías, el despertar no es más que salvarse del trauma que genera ese viaje (las violentas objetivaciones ) para, llegado el salto dialéctico, recuperar lo que ya había y siempre hubo, ya no antes de la existencia del hombre sino en el potencial de las relaciones sociales que él creó una vez estas queden liberadas de la enajenación, pues, conscientes del deber (humano) en la realidad concreta.

46. Bauman hace un análisis del desplazamiento que sufre la relación cartesiana entre sujeto y objeto hacia el espacio de la alienación. En su razonamiento distingue dos etapas: (i) Los sujetos (demostrados a sí mismos en la acción de buscar de la que son capaces) primero establecen sus necesidades materiales, después estructuran los conjuntos de clasificación y matrices de evaluación para ordenar el mundo de los objetos. El fin es simple: dominarlos. (ii) Los sujetos, en la costumbre adquirida de sentir el mundo a partir del dominio material sobre todo lo inanimado, aplican la misma lógica "a las relaciones entre seres humanos o entre categorías de seres humanos (como con la clasificación aristotélica que situaba a los esclavos entre las "herramientas que hablan»), un modo que tiende a tratar a los humanos de acuerdo con los patrones elaborados y destinados a los cosas". Por consiguiente, emerge una categoría de personas carentes de conciencia, motivaciones y voluntad, y que pue- dad de que el sujeto se ponga a sí mismo en entredicho, es decir, sin tomar partido ante su estado amnésico del deber que tiene como hombre (por ser un sujeto pensante): el de evaluar sus propias convicciones y actos prácticos en base a la experiencia material que le rodea (atento a los efectos comprobables y evidentes que él produce en el mundo).

La reducción de la alineación, tanto en Marx como en Bauman, pasa por reducir a la nada todo aquello que causa el sufrimiento humano ${ }^{47}$. Nadie puede cam-

den ser negados como generadores y receptores de empatía y compasión. A partir de esta mentalidad no es raro entender que fluya la noción de que los parados de larga duración o el desempleo estructural están compuestos por "seres humanos redundantes". Véase Bauman, Zygmunt ¿La riqueza de unos pocos nos beneficia a todos? Paidós, Barcelona, 2014, pp. 25 y 94-95. Otro ejemplo de esta lógica es el lenguaje económico y financiero que es utilizado para realizar pronósticos sobre el futuro de la historia y las opciones políticas de la sociedad para enfrentarse a la siguiente crisis. Véase la entrevista en EL PAIÍS a la economista jefe del banco HSBC, Janet Henry (del 30 diciembre de 2018). En esta, titulada "El crecimiento mundial ha tocado techo", la ideología radicalmente conservadora y racista del presidente de Brasil, Jair Bolsonaro, es asumida y obviada siempre y cuando sea capaz de cumplir con "(...) las reformas estructurales necesarias. Si consigue realizar cambios es posible que el sentimiento de los invesores internacionales mejore".

47. Para Marx, por ejemplo, la salida de la alienación de las religiones corría adherida al fin último de su pensamiento: si las condiciones (de existencia) inhumanas desaparecieran del mundo, la causalidad necesaria sería que, entre otras muchas supresiones, la religión quedaría evaporada, prescindible como un sostenedor del orden. Véase op. cit., Calvez, p. 59. No obstante, aunque en los círculos intelectuales de los países cristianos más desarrollados la alienación de las religiones se considera un elemento superado desde hace dos siglos, lo cierto es que todavía en la 
biar la humanidad salvo la propia humanidad por su humanidad (el carácter del diagnóstico mostrado hasta aquí es un filamento propedéutico para atravesar la puerta que debería permitir que lleguen el Bien y la Belleza al mundo social).

\section{Los líquidos sociales del amor y el consumo}

Los análisis didácticos de Bauman desembocan en un mensaje fácil de entender y quizás, a estas alturas, desprovisto políticamente del potencial crítico que cabría esperar de su recepción en una sociedad racional y ética:

(...) el camino de la felicidad pasa por ir de compras. Desde este postulado, la suma total de las compras de un país es la medida principal y más fiable de la felicidad de una sociedad, y el tamaño de lo que cada uno

práctica política continúa siendo un factor remanente de la ideología, de modo que el capitalismo todavía la articula (con la diversidad de credos disponibles, como el protestante, el musulmán, el hinduismo, el judaísmo, etcétera) como un mecanismo eficaz para retardar o impedir la supresión de alienaciones más poderosas y transversales (que afectan a creyentes y ateos por igual), sin responsabilizarse de los efectos secundarios que produce dicha estrategia de "subvención" (entre otros, el ensalzamiento del nacionalismo, la justificación del racismo, la dominación de mujeres e indígenas, y la servilidad de los débiles y desfavorecidos económica y culturalmente). Para evitar malentendidos con respecto a este último razonamiento, la "subvención" que denunció suprime o domeña el programa ético de las religiones en la práctica política, es decir, se adopta un pacto tácito a tres bandas, entre el funcionamiento del mercado, el Estado y las instituciones religiosas, para aceptar una derilección que afecta, en este caso, a la "propiedad" de la exégesis de la moral y, consiguientemente, se refuerza, gracias a ella, la adiaforización general. representa en ese conjunto de compradores es la medida principal y más fiable de la felicidad temporal. ${ }^{48}$

La felicidad ha quedado cercenada de su propósito primigenio (indiscutiblemente mitificado por el arte y la evasión de la realidad): el amor; un significante enigmático sobre el que el consumismo opera concienzudamente para desarmarlo de su capacidad para debilitar la carga del narcisismo y desublimar la compulsiva resolución del deseo que la imagen del espejo reificado devuelve a la conciencia de nosotros mismos: la meta existencial (alineada) es el placer, por tanto, (la perversión) trata de alcanzar, y si puede ser por poco dinero, la multiplicación exponencial de los "momentos de júbilo, arrebato o éxtasis" con los que compensar el dolor y los sacrificios que la vida, con sus obligaciones productivas, nos exige.

Debe quedar claro que el deseo y el amor son senderos diferentes (o de sentido opuesto), pero sucede que en contadas ocasiones se cruzan. Para Bauman, el deseo es "el anhelo de consumir"49 por el motivo de que consumir nos produce atracción hacia la presencia de objetos que son externos a nosotros. En la deducción con la que prosigue Bauman, de claras raíces psicoanalíticas además de filosóficas, el deseo implica la voluntad de "despojar la alteridad de su otredad"50, es

48. Op. cit., Bauman, p. 67.

49. Bauman, Zygmunt. Amor líquido. Acerca de la fragilidad de los vínculos humanos. Fondo de cultura económica, Madrid, 2005, p. 24.

50. Ídem. En general, la alteridad hay que entenderla como lo que no somos (y lo que somos frente al Otro), pero que forma parte de la unidad o del número, de lo que se infiere que hay un deber de ponerme en el lugar de este otro rostro para poder comprenderlo. Ahora bien, cuando el deseo (que es el goce) del otro se impone en 
decir, de expulsar su poder de ser como división de mí, para hacerme su dueño aunque sin el riesgo de recibir tentaciones (es decir, sin tener que amarlo). Ahora, en cambio, el amor tiene un sentido específico que se diferenciaría del deseo del siguiente modo:

El amor es la supervivencia del yo a través de la alteridad del yo. Y por eso, el amor implica el impulso de proteger, de nutrir, de dar refugio, y también de acariciar y mimar, o de proteger celosamente, cercar, encarcelar. Amar significa estar al servicio, estar a disposición, esperando ordenes, pero también puede significar la expropiación y confiscación de toda responsabilidad. ${ }^{51}$

Para reanalizar el alcance profundo de esta síntesis me remito, como estratégica discursiva, a centrar el foco en otra síntesis, la acometida por Lacan a propósito de la estructura del amor en "El Banquete" de Platón. Así y en primer lugar, para articular el propio concepto hay que asumir que el amor es, ante todo, una metáfora y, como tal, funciona con una lógica de sustitución. Lo amplío: una realidad que se expresa por medio de otra realidad en la que se manifiesta, de una forma más clara o menos velada, un nexo o constan-

mi conciencia, lo que sucede es que quiero arrebatarle la otredad (su voluntad de querer ser otro diferente de mí), es decir, me he introducido en su discurso pero no para entenderlo, cediéndole el reconocimiento de su derecho a ser, sino para dominarlo (y en el caso del amor, para poseerlo). La alteridad, en el contexto aludido, al estar localizado en el mecanismo del deseo, surge como un reflejo de la pulsión de destrucción, puesto que una vez se consume (pues lo mastico), esta queda convertida en un desecho, de manera que la satisfacción que obtengo de "masticarlo" enseguida se desvanece: lo que se percibe al final del proceso de consumo por el mismo sujeto es la presencia de la pulsión de muerte.

51. Ibidem., p. 25. te presente en ambas (y objetivada por la compartición de semas que dialogan entre sí). Lo que nos remite a que el amor, en su capacidad infinita de abstracción, es capaz de unificar en sus límites una significación que diríamos sintética y simultánea (fruto del movimiento de la dialéctica), generando una expectativa de cambio y a la vez una posibilidad experiencial que desemboca en un placer concreto e inédito por la conjunción de lo que antes discurría mediante significantes nítidamente separados o que se alejaban entre sí. En segundo lugar, "el amor, es dar lo que no se tiene"52, lo cual hay que restituirlo dentro de cómo tiene lugar el proceso de amor, es decir, en su devenir dentro de una tensión entre la función del amante y la del amado ${ }^{53}$, lo cual, en otras palabras, sugiere que la función de cada uno es una sustitución de la dicotomía entre el ansia de poseer y el de ser poseído, luego el juego del poder nutre el proceso del amor. Volviendo a "El Banquete", un elogio del amor (epainos), en la que cada invitado presente en el ágape hace una exposición sobre su particular visión y experiencia sobre este enigma. La dispa-

52. Lacan, Jacques. Seminario 8: La transferencia en su disparidad subjetiva, su pretendida situación, sus excursiones técnicas (1960-61). Escuela freudiana de Buenos Aires, Buenos Aires, 2002, p. 24.

53. "(...) el amante como el sujeto del deseo, con todo el peso que tiene para nosotros este término, el deseo - y al eromenos, al amado, como aquel que, en esa pareja, es el único en tener alguna cosa (...) lo que caracteriza al erastes, al amante, para todos aquellos que se acercan a él, ¿no es esencialmente lo que le falta? Nosotros, podemos añadir en seguida que él no sabe lo que le falta, con ese acento particular de la inciencia que es el del inconsciente. Y por otra parte, el eromenos, el objeto amado, ¿no se ha situado siempre como aquel que no sabe lo que tiene, lo que tiene oculto, y que constituye su atractivo?". Ibidem., p. 25. 
ridad se muestra, por ejemplo, en Agatón con su descripción pacífica de un amor que amansa y reconcilia ${ }^{54}$. Mientras que en Pausanias ${ }^{55}$, el concepto se enriquece semánticamente mediante un aprendizaje de valoraciones que nos aproxima a una lectura utilitarista ${ }^{56}$ de plena actuali-

54. "El Amor es el que da «paz a los hombres, calma a los mares, silencio a los vientos, lecho y sueño a la inquietud.» Él es el que aproxima a los hombres, y los impide ser extraños los unos a los otros; principio y lazo de toda sociedad, de toda reunión amistosa, preside a las fiestas (...)". Platón. Obras completas. Edición de Patricio de Azcárate, tomo 5, Madrid 1871, p. 330.

55. "El Amor, como dije al principio, no es de suyo ni bello ni feo. Es bello, si se observan las reglas de la honestidad; y es feo, si no se tienen en cuenta estas reglas. Es inhonesto conceder sus favores a un hombre vicioso o por malos motivos. Es honesto, si se conceden por motivos justos á un hombre virtuoso. Llamo hombre vicioso al amante popular que ama el cuerpo más bien que el alma; porque su amor no puede tener duración, puesto que ama una cosa que no dura. Tan pronto como la flor de la belleza de lo que amaba ha pasado, vuela a otra parte, sin acordarse ni de sus palabras ni de sus promesas. Pero el amante de un alma bella permanece fiel toda la vida, porque lo que ama es durable. Así, pues, la costumbre entre nosotros quiere que uno se mire bien antes de comprometerse; que se entregue á los unos y huya de los otros; ella anima a ligarse a aquellos y huir de estos (...) si con una esperanza de utilidad o de ganancia se entrega uno a un amante, que se creía rico, que después resulta pobre, y que no puede cumplir su palabra, no es menos indigno, porque es ponerse en evidencia y demostrar que mediando el interés se arroja a todo, y esto no tiene nada de bello. Por el contrario, si después de haber favorecido a un amante, que se le creía hombre de bien, y con la esperanza de hacerle uno mejor por medio de su amistad, llega a resultar que este amante no es tal hombre de bien y que carece de virtudes, no es deshonroso verse lino en este caso engañado". Ibidem., Platón, pp. 313-314.

56. Lacan no se resiste a transferir el carácter económico de Pausanias a la psicología del cal- dad en el contexto del sujeto (consumidor); el que aprende a amar, antes que nada, (deseando) consumiendo objetos; del que nos habla Bauman ${ }^{57}$. Se podría decir que Platón antecede el componente crítico recomenzado por Bauman cuando aquel designa con un flemático sentido de humor el criterio oculto, hipócrita e individualista contenido en el "falso" discurso de Pausanias ${ }^{58}$. Platón, sobre su posición ética sobre el amor, nos habla con silen-

vinismo: "Era un rico calvinista (...) No pienso que sea el privilegio del calvinismo producir ricos, pero no carece de importancia dar la indicación de esto, pues de todos modos se puede observar que la teología calvinista ha tenido este efecto de hacer aparecer, como uno de los elementos de la dirección moral, que es en esta tierra que Dios colma de bienes a los que ama. En otra parte también, quizá, pero desde esta tierra. Que la observación de los mandamientos divinos tiene por fruto el éxito terrestre, no ha carecido de fecundidad en todo tipo de empresas. Como quiera que sea, el calvinista en cuestión trataba el orden de los méritos que adquiría para sí desde esta tierra para el mundo futuro, exactamente en el registro de la página de una contabilidad-Tal día, comprada tal cosa. Y todas sus acciones estaban dirigidas en el sentido de adquirir para el más allá una caja fuerte bien llena". Véase op. cit., Lacan. Seminario 8, clase 4: La psicología del rico, p. 14. Ciertamente, es fácil vislumbrar la escala de valores que termina por ser establecida en el discurso de Pausanias, y es por ello que su contemporaneidad se intensifica por aquello que niega.

57. "Si el deseo ansía consumir, el amor ansía poseer". Véase op. cit., Bauman, p. 25

58. Cuando Pausanias acaba su alegato, el turno le correspondía a Aristófanes, a quien le sobreviene un fuerte hipo, teniendo que ceder su puesto a Eriximaco. Lacan cita en su comentario una pista que le proporcionó Kojève para argumentar que la actitud de Aristófanes es, en realidad, una burla hacia todo lo expuesto por Pausanias (el hipo le sobreviene por haber estado destornillado de la risa durante la alocución de este). Ibidem., Lacan, pp. 20-21. 
cios, hipos y por boca de Sócrates ${ }^{59}$, pero el conjunto de esta obra que he traído a colación no es sino una radiografía política (moral) de su época (tan diferente y a la vez tan familiar). En correspondencia con Bauman, Platón estaría de acuerdo en la relación de atracción versus repulsión que se da entre el deseo (que aniquila su objeto) y el amor que "crece con sus adquisiciones y se satisface con su durabilidad"60. En la lógica de Platón, se desea (y se ama) lo que no se posee en el presente, lo que no se está seguro de poseer todavía, y lo que se quiere seguir poseyendo en el futuro ${ }^{61}$ (he ahí el punto de encuentro con el análisis de Bauman sobre la especificidad del comportamiento del amor en oposición al deseo limitado a consumir).

Una vez realizada esta concentrada disquisición sobre la naturaleza del amor se puede entender con menor ambigüedad la crítica a la razón "líquida"62 que arma

59. La ciencia de lo bello emerge como el fin supremo (del Amor) y denota el propósito de convertirse en un sabio en la materia. Precisamente, esto se sustenta en que la tarea de Sócrates era la de trascender la doxa y alcanzar el episteme (la ciencia o saber que da cuenta de sus razones). Sin embargo, Platón, en la penúltima intervención de Sócrates, se aproxima al rol de un analista de la psique (y del irracional inconsciente) y nos anuncia la pregunta clave (la raíz): ¿Amor de qué? En concreto: "¿el Amor es el amor de una cosa o de nada?" Y continúa con la huella de lo que nos devuelve al terreno acotado por Bauman (interrogando Sócrates a su esforzado Agatón sobre si el Amor desea la cosa que él ama, concluye así: "mira si no es más bien necesario que el que desea le falte la cosa que desea, o bien que no la desee si no le falta"). Véase op. cit., Platón, pp. 333.

60. Ídem., Bauman.

\section{Ibidem., Platón, p. 334.}

62. El significante "líquida" que da propiedad a "razón" se desplaza hacia un territorio de significados relacionados con lo volátil, lo inestable,
Bauman al cerciorarse de que el amor (el deseo de poseer), que aprendía y practicaba el sujeto (como categoría de homo faber) por medio de la cultura que le fue transmitida por la incipiente sociedad industrial, y que a su vez él estaba construyendo, tenía una propiedad esencial: la durabilidad del compromiso, equivalente a la durabilidad de los objetos que eran producidos en el inicio. Por el contrario, en la sociedad posindustrial esa propiedad ha sido escindida, rota, desatando

lo incierto e inconsistente $\mathrm{y}$, al mismo tiempo, adquiere la propiedad singular de lo que resulta ser incontenible (lo que se mueve, desliza o propaga rápida y fácilmente por cualquier espacio o medio, pues, que su contención es difícil). La metáfora de la razón líquida funciona como sustitución (alteración) del uso teórico y práctico de la razón que concebía Kant. Recordemos que, para este último, el uso teórico de la razón es "aquel mediante el cual conozco a priori (como necesario) que algo es". En cambio, el uso práctico es "aquel por medio del cual se conoce a priori qué debe suceder (...) hay leyes prácticas que son absolutamente necesarias (las morales)". Finalmente, Kant postuló que la razón "no produce conceptos (de objetos), sino que simplemente los ordena", es decir, el objeto es construido por nosotros (por el entendimiento) por medio de la síntesis dialéctica. En el salto alegórico que propone Bauman, el uso de la razón no ordena moralmente a priori qué debe suceder, sino que las leyes prácticas necesarias son desplazadas por el potencial de gratificación del objeto en el plano teórico. Luego el objeto es construido en base a nuevas leyes prácticas que permiten la distensión de las contradicciones dialécticas: su fin es mitigar, diluir y neutralizar las "ataduras" (las cuales, para Bauman, suponían una prueba del ingenio cultural de la sociedad). Por consiguiente las categorías (que ordenan o guían el entendimiento) y que dan "concordancia entre el concepto y el objeto", han sido distorsionadas o sustituidas por otras categorías, las cuales son las que crean la ilusión que funda la racionalidad líquida (como otro lenguaje de la alienación) que opaca la verdad. Véase op. cit., Kant, pp. 525 y $530-531$. 
una cultura que "ve opresión en los compromisos duraderos; los vínculos durables despiertan su sospecha de una dependencia paralizante. Para la moderna racionalidad líquida del consumo, no existen ni necesidad ni uso que justifiquen su existencia"63.

Ante tal perspectiva pocas dudas quedan sobre el hecho de que el amor (como fenómeno dentro de la cultura) ha sido definitivamente (parafraseando a Lacan) desengranado de la Belleza, y con ello el potencial sexual (con su responsabilidad hacia el Otro) ha quedado despojado de su función de "constructor" dentro de la sociedad: el sujeto consumidor resultante se hace con las riendas de ese potencial y lo abre "hacia modos novedosos e imaginativos" 64 que quedan determinados en el fondo de su motivación por la lógica de las relaciones con los objetos. En otras palabras, y solapando las dos realidades, se diría que el potencial sexual queda concebido bajo las mismas leyes de la práctica del deseo (de las posibilidades) de consumir (y de no poder hacerlo):

La vida útil de los bienes por lo general sobrevive a la utilidad que tienen para el consumidor. Pero si son usados repetidamente, los bienes adquiridos frustran la búsqueda de la variedad, y el uso sostenido hace que pierdan su lustre y su brillos. Pobres aquellos que, por escasez de recursos, están condenados a usar bienes que ya no prometen sensaciones nuevas e inexploradas (...) ellos son los excluidos de la sociedad de los consumidores, son los consumidores fallidos, los inadecuados e incompetentes, los fracasados. ${ }^{65}$

63. Ibidem., Bauman, p. 70.

64. Ibidem., p. 72.

65. Ibidem., p 73.
La inseguridad integral que sienten las personas (porque les viene por todas partes), y que les produce una ansiedad con un acento redomado, surge de perder el derecho a consumir y, por extensión, de verse forzados a establecer relaciones sexuales que excedan lo episódico (la duración óptima es una cuestión central para la vida líquida, teniendo que ser uno, el mensaje, cada vez más directo, breve o de "ir al grano" para cualquier forma de comunicación humana que despierte la curiosidad del otro y la atención del público), por ende, ese temor acelera la huida de todas las causas que pueden hacer que, como si fuera una enfermedad maldita por la cultura, vuelvan a clavarse los grilletes del compromiso en la conciencia del sujeto hasta poseer el destino de su misma identidad sexual66.

Así, Bauman configura críticamente el ecosistema social por el que deambulan el homo consumens y el homo sexualis; cada cual como registro de la marcha sin propósito ético (universal) de la razón posmoderna. Este último arquetipo (sexualis) es sumamente relevante, ya que la insatisfacción (el ansia que se agudiza por no consumir) no queda restringida a la comarca de los objetos inanimados, sino que alcanza las puertas de un nuevo catálogo, el de las identidades sexuales, dado que se consolida; por medio de la razonabilidad del mercado (que entiende los motivos para cualquier tipo de necesidad, incluso la necesidad de la nada) y

66. "¿Qué tipo de compromiso, si es que lo hay, establece la unión de dos cuerpos? ¿De qué manera, si es que de alguna, compromete el futuro de ellos? ¿Es posible mantener el encuentro sexual aislado del resto de los objetivos de vida, o acaso se invadirá (tenderá a hacerlo, se permitirá que lo haga) el resto de los aspectos de la vida, saturándola y transformándola?". Ibidem., p. 74. 
con la ciencia a su servicio; la alterabilidad de todo aquello que se consideraba anteriormente como inalterable. Y esto es, si no un estadio de la propia insatisfacción como el signo esencial del lenguaje de la posmodernidad, al menos, un reflejo de una angustia e inseguridad infinitas:

La vida del homo sexualis está, por tanto, plagada de angustias. Existe siempre la sospecha de que estamos viviendo en la mentira o en el error, de que algo de importancia crucial se nos ha escapado, perdido o traspapelado, de que algo hemos dejado sin explorar o intentar, de que existe una obligación vital para con nuestro yo genuino que no hemos cumplido, o de que alguna posibilidad de felicidad desconocida y completamente diferente de la experimentada hasta el momento se nos ha ido entre las manos o está a punto de desparecer para siempre si no hacemos nada al respecto. ${ }^{67}$

\section{La escuela de Bauman: esperanza para la acción moral}

El sufrimiento continúa su reino en la tierra, a pesar de los vestigios de prosperidad aparente que la globalización va distribuyendo a medida que expande la producción en unos extremos del mundo y los contrae en otros. Lo cierto es que se generan dos tensores en la conciencia del individuo que trata de decidir qué hacer y cómo reaccionar ante el conocimiento que tiene de lo que es desigual e injusto. Así, el primer tensor es que nunca antes la especie humana, como audiencia, tuvo a su alcance tantas imágenes en directo de los horrores, el hambre, la miseria, la corrupción, la muerte y el mal que castiga

67. Ibidem., p. 79. la realidad fáctica que captamos con los sentidos (la cuestión relevante aquí es si sabemos todo de lo que somos capaces y si nos importa). El segundo tensor es la consiguiente división del very el saber versus qué se hace y qué se debería hacero.

Es un hecho cotidiano el acostumbramiento a lo incómodamente feo, a la aptitud de volverse indiferente o de simplemente (por lo estrechamente cercano) hacer uso de una falta de reacción que no recibe censura o sanción de ninguna autoridad. Esta ausencia de crítica (de exculpación sobre una revisión del pecado del que somos testigos y del que nos contagiamos) se está complementando con un tedio incremental hacia la indagación del por qué, de manera que la disonancia en lo cognitivo se hace absoluta, y la posibilidad de comprender la realidad cae en el vacio, en un imparable retroceso (las causas se nos escapan o creemos que son tan obvias e insubsanables que abandonamos la reflexión de ellas, pues, ya nada tienen que ver conmigo). El veredicto de Bauman refleja la problemática de nuestra época histórica:

(...) el problema es que a diferencia del pasado, la magnitud de nuestra conciencia del destino de los otros y el alcance de nuestra capacidad de afectar ese destino (ya sea para dañarlo o separarlo) no se superponen (...) Solo una parte relativamente pequeña de los resultados y repercusiones de nuestros actos está sujeta a regulación ética o

68. “(...) la brecha entre lo hecho y lo que hay que hacer parece ensancharse en vez de decrecer. Cada vez hay en el mundo más asuntos turbios que piden venganza o remedio a los gritos, pero nuestra capacidad de actuar, y particularmente la aptitud para actuar con eficacia, parece ir marcha atrás, empequeñecida aun más por la colosal tarea". Bauman, Zygmunt. La sociedad sitiada. Fondo de cultura económica, Buenos Aires, 2004, p. 258. 
guiada por sentimientos morales; pocos actos toman en consideración los posibles efectos que tendrán mas allá de los destinatarios o los participantes presentes. ${ }^{69}$

No es tarea fácil, ni teórica ni práctica, elucidar la solución al problema a no ser que primero entendamos cómo hay que plantear un problema. El propósito (y el ideal) del combate político (de las ideas universales y de los cuerpos que son materia) al que me despierta el viaje hacia Bauman es el sueño utópico de alcanzar la certeza apodíctica que Kant deseaba para la mayoría de edad de una sociedad (el ansia de poseerla de un modo no dialéctico, dejando atrás su carácter problemático). Pero ¿es esto posible? ¿e ir más allá?:

Un mayor grado de libertad civil parece provechosa para la libertad espiritual del pueblo $y$, pese a ello, le coloca límites infranqueables; en cambio un grado menor de esa libertad civil procura el ámbito para que esta libertad espiritual se despliegue con arreglo a toda su potencialidad. Pues, cuando la naturaleza ha desarrollado bajo tan duro tegumento ese germen que cuida con extrema ternura, a saber, la propensión y la vocación hacia el pensar libre, ello repercute sobre la mentalidad del pueblo (merced a lo cual este va haciéndose cada vez más apto para la libertad de actuar) y finalmente acaba por tener un efecto retroactivo hasta sobre los principios del gobierno, el cual incluso termina por encontrar conveniente tratar al hombre, quien ahora es algo más que una máquina, conforme a su dignidad..$^{70}$

Ni soy como una máquina ni como objeto alguno que se haya producido salvo por

69. Aquí la solución que deja caer para el hombre mortal (inspirado por Ulrich Beck) son las "soluciones biográficas a contradicciones sistémicas". Ibidem., p. 263.

70. Kant. Immanuel ¿Qué es la Ilustración? Alianza editorial, Madrid, 2013, p. 98. el hombre mismo. Despierto: soy cuerpo. $Y$ soy concreto. Ahora contesta Bauman; otra vez os dejo con él:

Juzgar la vida "como es" en función de la vida como debería ser (es decir, una vida que se imagina diferente de la vida conocida, y particularmente una vida que sería mejor y preferible a aquélla) es un rasgo definitivo, constitutivo de la humanidad (...) Lo que impulsa a la vida humana y la mantiene encaminada es la necesidad de trascender. La trascendencia -la transgresión- es la modalidad del ser-en-el-mundo de los humanos. Impedir la transgresión y/o rehuirla señalan una patología de ese ser (...) Para que la constante urgencia por trascender se articule en proyectos, deben cumplirse condiciones especiales; la naturaleza de estas condiciones definirá la forma de las articulaciones posibles (...) La utopía es una de esas formas de articulación. Las condiciones que definieron esa forma fueron las de la modernidad en su estadio inicial "sólido". ${ }^{71}$

71. Ibidem., Bauman, pp. 271-272. La trascendencia es sustituida por él mismo bajo el apelativo de "transgresión", lo que significa, en la cultura del lenguaje oficial del Estado, "la violación de un precepto o una ley", por ello, desde mi análisis, el "pesimismo" con el que se ha querido categorizar popularmente el mensaje de Bauman sería indebido salvo si con ese segundo denominador se quiere significar que su mensaje es ante todo dialéctico (lo cual adquiere concordancia con la acción de transgredir). Si este fuera el caso tendría entonces una cortés afinidad con la ética geométrica de Marx, que radicaba en que el hombre coincidiera perfectamente con lo real, es decir, que la responsabilidad ética del hombre debía ser "que se haga lo que es, que realice su esencia dentro de su apariencia, que adopte el ritmo de la experiencia única y total", una síntesis dialéctica que contenía igualmente el argumento de que el hombre tiene una vocación universal y genérica: la naturaleza del hombre es su relación con el otro hombre (como totalidad, pues, con la humanidad). La trascendencia para Bauman, influido por Levinas, es una marcha humanista (como en 
Evocando a Ralph Waldo Emerson a través de la mirada de Erich Fromm, "las cosas y la circunstancias que nosotros mismos hemos creado"72 nos dominan desde lo más profundo, y por esta razón es una ley necesaria el despertar a la acción ética, volver a ser un individuo que actúa conforme a ella. La idea política y moral de una humanidad imaginanda como unidad está todavía por hacer, e igualmente el renacimiento humanista volverá a coger las riendas.

el joven Marx) hacia la salvación de la humanidad dentro de la sociedad (por ende, exenta de la concepción del eterno retorno a la naturaleza que dominó en el marxismo después de Marx), aunque siendo consciente de que la historia no progresa linealmente, sino zigzagueando, y, más todavía, que la historia cuando avanza en el tiempo y en el espacio lo hace por la acción libre del hombre, oponiéndose (negando) y combatiendo lo que en la sociedad hay en contra de esa relación vocacional con el otro hombre, con la tarea de vaciarla (dicha relación social) de alineaciones y privaciones mediante negaciones de negaciones que enriquecerían el devenir y también la imaginación utópica (por medio de este segundo concepto se daría el salto de lo cualitativo a lo cuantitativo ajustado a la lógica de Hegel, pues, en dirección contraria a la lógica de Lenin) pese a que por momentos se desaten repeticiones y pérdidas contra la dignidad del hombre. Véase también op. cit., Calvez p. 493.

72. Fromm, Erich, El humanismo como utopía real. Paidós, Barcelona, 2007, p. 40. 